University of Nebraska - Lincoln

DigitalCommons@University of Nebraska - Lincoln

\title{
The influence of plants on atmospheric methane in an agriculture- dominated landscape
}

\author{
Xin Zhang \\ Yale University, xin.zhang@yale.edu \\ Xuhui Lee \\ Yale University \\ Timothy J. Griffis \\ University of Minnesota, tgriffis@umn.edu \\ John M. Baker \\ USDA-ARS, john.baker@ars.usda.gov \\ Matt D. Erickson \\ University of Minnesota, eric1554@umn.edu
}

See next page for additional authors

Follow this and additional works at: https://digitalcommons.unl.edu/usdaarsfacpub

Zhang, Xin; Lee, Xuhui; Griffis, Timothy J.; Baker, John M.; Erickson, Matt D.; Hu, Ning; and Xiao, Wei, "The influence of plants on atmospheric methane in an agriculture-dominated landscape" (2013). Publications from USDA-ARS / UNL Faculty. 1332.

https://digitalcommons.unl.edu/usdaarsfacpub/1332

This Article is brought to you for free and open access by the U.S. Department of Agriculture: Agricultural Research Service, Lincoln, Nebraska at DigitalCommons@University of Nebraska - Lincoln. It has been accepted for inclusion in Publications from USDA-ARS / UNL Faculty by an authorized administrator of DigitalCommons@University of Nebraska - Lincoln. 
Authors

Xin Zhang, Xuhui Lee, Timothy J. Griffis, John M. Baker, Matt D. Erickson, Ning Hu, and Wei Xiao 


\title{
The influence of plants on atmospheric methane in an agriculture-dominated landscape
}

\author{
Xin Zhang • Xuhui Lee • Timothy J. Griffis • \\ John M. Baker • Matt D. Erickson • Ning Hu • Wei Xiao
}

Received: 4 October 2012 /Revised: 15 March 2013 / Accepted: 22 March 2013

(C) ISB 2013

This article is a U.S. government work, and is not subject to copyright in the United States.

\begin{abstract}
The primary objective of this study was to clarify the influence of crop plants on atmospheric methane $\left(\mathrm{CH}_{4}\right)$ in an agriculture-dominated landscape in the Upper Midwest of the United States. Measurements were carried out at two contrasting scales. At the plant scale, $\mathrm{CH}_{4}$ fluxes from soybean and corn plants were measured with a laser-based plant chamber system. At the landscape scale, the land surface flux was estimated with a modified Bowen ratio technique using measurements made on a tall tower. The chamber data revealed a diurnal pattern for the plant $\mathrm{CH}_{4}$ flux: it was positive (an emission rate of $0.4 \pm$ $0.1 \mathrm{nmol} \mathrm{m}{ }^{-2} \mathrm{~s}^{-1}$, average of soybean and corn, in reference to the unit ground area) during the day, and negative (an uptake rate of $-0.8 \pm 0.8 \mathrm{nmol} \mathrm{m} \mathrm{m}^{-2}$ ) during the night. At the landscape scale, the flux was estimated to be $14.8 \mathrm{nmol} \mathrm{m}^{-2} \mathrm{~s}^{-1}$ at night and highly uncertain during the day, but the available references and the flux estimates from the equilibrium methods suggested that the $\mathrm{CH}_{4}$ flux during the entire observation period was similar to the estimated nighttime flux. Thus, soybean and corn plants have a negligible role in the landscape-scale $\mathrm{CH}_{4}$ budget.
\end{abstract}

\footnotetext{
X. Zhang $(\bowtie) \cdot$ X. Lee

School of Forestry and Environmental Studies, Yale University,

New Haven, CT, USA

e-mail: xin.zhang@yale.edu

T. J. Griffis $\cdot$ M. D. Erickson

Department of Soil, Water, and Climate, University of Minnesota, St Paul, MN, USA

J. M. Baker

Agricultural Research Service, USDA, St Paul, MN, USA

N. Hu $\cdot$ W. Xiao

Yale-NUIST Center on Atmospheric Environment, College of Applied Meteorology, Nanjing University of Information Science and Technology, Nanjing, Jiangsu, China
}

Keywords Methane $\cdot$ Corn $\cdot$ Soybean $\cdot$ Agriculture $\cdot$ Land surface flux $\cdot$ Footprint analysis

\section{Introduction}

Methane $\left(\mathrm{CH}_{4}\right)$ represents one of the primary greenhouse gases, and estimates of its terrestrial sinks and sources are subject to large uncertainties. To date, most studies have focused on $\mathrm{CH}_{4}$ emissions from wetlands/peatlands, agricultural feed lots/lagoons, and municipal waste sites (Le Mer and Roger 2001; Mosher et al. 1999; Shurpali et al. 1993; Shurpali and Verma 1998). Recently, Keppler et al. (2006) suggested that the $\mathrm{CH}_{4}$ flux of terrestrial vegetation may range from 62 to $236 \mathrm{Tg}$ year $^{-1}$, accounting for $12 \%$ to $45 \%$ of global terrestrial emissions (Nisbet et al. 2009). The plant pathway of aerobic $\mathrm{CH}_{4}$ generation suggested by Keppler et al. has led to a reevaluation of $\mathrm{CH}_{4}$ sources and stimulated a new debate regarding the role of plants in greenhouse gas mitigation strategies (Butenhoff and Khalil 2007; Dueck and Van Der Werf 2008; Nisbet et al. 2009; Parsons et al. 2006). In this study, we examined the influence of agricultural crops (corn and soybean) on the plantscale and landscape-scale $\mathrm{CH}_{4}$ budget. Given the large spatial extent of corn and soybeans grown in the United States (US), their high net primary productivity, and the large nutrient inputs used to support these systems [US Department of Agriculture (USDA) 2009], we hypothesize that their influence on atmospheric $\mathrm{CH}_{4}$ is important during the growing season and aim to better understand the underlying mechanisms.

At the plant scale, researchers have reported that $\mathrm{CH}_{4}$ emissions are often below detection limits (Beerling et al. 2008; Dueck et al. 2007; Kirschbaum and Walcroft 2008), while others have demonstrated significant emissions for many plant species (Keppler et al. 2006, 2009; Vigano et al. 2008; Wang et al. 2008; Qaderi and Reid 2011). Even for 
the same species, the findings are not consistent. For example, in previous studies, the $\mathrm{CH}_{4}$ flux for corn (Zea mays) ranged from $-0.43 \mathrm{nmol} \mathrm{m} \mathrm{s}^{-1}$ to $11 \mathrm{nmol} \mathrm{m}^{-2} \mathrm{~s}^{-1}$ (Table 1). The discrepancy among the published studies on plant-scale $\mathrm{CH}_{4}$ flux can be attributed to mechanisms of $\mathrm{CH}_{4}$ production in plants and experimental artifacts. Evidence suggests that abiotic stress may stimulate the production of $\mathrm{CH}_{4}$ resulting from higher temperature, water stress, exposure to sodium azide, and other environment factors that increase the availability of reactive oxygen species in plants (Bruhn et al. 2009, 2012; Qaderi and Reid 2011; Wang et al. 2011; Wishkerman et al. 2011). The $\mathrm{CH}_{4}$ production caused by abiotic stress can be significant. For example, $\mathrm{CH}_{4}$ emission from six species of crop leaves increased by $20 \%$ when the temperature was increased from $24{ }^{\circ} \mathrm{C}$ to $30{ }^{\circ} \mathrm{C}$ during the day, and from $20^{\circ} \mathrm{C}$ to $26^{\circ} \mathrm{C}$ at night (Qaderi and Reid 2011). As a result, different levels of abiotic stress, caused either by chamber artifacts or by different environmental conditions, can cause differences in the observed $\mathrm{CH}_{4}$ flux.

There are four main types of chamber artifacts that can bias the observed $\mathrm{CH}_{4}$ flux from plants. First, evidence indicates that the $\mathrm{CH}_{4}$ flux is lower in the dark than if the plant is exposed to UV radiation (McLeod et al. 2008; Vigano et al. 2008, 2009), indicating that measurements made in artificial light environments may underestimate $\mathrm{CH}_{4}$ emissions. Second, several experiments have involved detached plant tissues (Wang et al. 2008; Vigano et al. 2008), and their detected $\mathrm{CH}_{4}$ emission may be caused by the physical damage associated with extracting tissue (Wang et al. 2009). Third, most plant chambers are characterized by increased temperature and humidity compared to ambient conditions (Keppler et al. 2006; Kirschbaum and Walcroft 2008; Nisbet et al. 2009), which can increase plant stress and bias the observed $\mathrm{CH}_{4}$ flux from plants growing in field conditions. Finally, in some experiments, the plants are immersed in a $\mathrm{CH}_{4}$-free gas or a gas with a low $\mathrm{CH}_{4}$ concentration to improve the sensitivity of the $\mathrm{CH}_{4}$ flux detection (Beerling et al. 2008; Keppler et al. 2006; Kirschbaum and Walcroft 2008; Vigano et al. 2008). This experimental design excludes the possibility of plant uptake and may lead to additional $\mathrm{CH}_{4}$ flux through the adsorption/desorption processes and through diffusion via the plant tissue driven by an enhanced concentration gradient between the leaf and the soil.

Agricultural ecosystems are heavily managed and cornsoybean rotations require significant nutrient input (Karlen et al. 1995). However, the impact of nitrogen enrichment on plant flux has not been addressed in the literature, while soil nitrogen has been studied extensively as a regulatory factor involved in soil $\mathrm{CH}_{4}$ flux. Nitrogen enrichment affects the production and consumption pathways of $\mathrm{CH}_{4}$ by increasing the redox potential and competing against $\mathrm{CH}_{4}$ to react with methane monooxygenase. For soils emitting $\mathrm{CH}_{4}$, nitrogen enrichment can increase the net emission by up to $97 \%$, while for soils absorbing $\mathrm{CH}_{4}$, nitrogen enrichment can suppress the uptake by $38 \%$ (Liu and Greaver 2009). We hypothesize that nitrogen enrichment should increase $\mathrm{CH}_{4}$ emission or suppress $\mathrm{CH}_{4}$ uptake from plants.

To date, most $\mathrm{CH}_{4}$ studies have been based on chamber techniques that have relatively poor temporal and spatial resolution. However, methane fluxes are known to be episodic (ebullition events can be triggered by changes in atmospheric pressure) and have been shown to vary significantly within similar field conditions (Hendriks et al. 2010; Kroon et al. 2007; Pattey et al. 2006; Smeets et al. 2009). The heterogeneity of $\mathrm{CH}_{4}$ flux implies that upscaling plotscale measurements (the bottom-up method) to estimate the regional $\mathrm{CH}_{4}$ budget will carry large uncertainties.

The tall tower top-down method can help constrain these uncertainties at regional scales. Few studies have attempted to measure the landscape-scale $\mathrm{CH}_{4}$ budget based on nearcontinuous monitoring of atmospheric mixing ratios. Using the Weather Research and Forecast (WRF) and the Stochastic Time-inverted Lagrangian Transport (STILT) model to interpret the $\mathrm{CH}_{4}$ concentration measured at a tall tower, Zhao et al. (2009) found that the $\mathrm{CH}_{4}$ emission was $37 \pm$ $21 \%$ higher than the bottom-up emission estimates. Another successful application of this approach was reported by Werner et al. (2003), who measured $\mathrm{CH}_{4}$ gradients at a $447-\mathrm{m}$ tall tower in Wisconsin, which is about $300 \mathrm{~km}$ from our Minnesota research site, in a landscape of wetland and upland forests. They found that the emission flux of the wetlands exceeded the uptake flux of the forests, resulting in a net regional $\mathrm{CH}_{4}$ flux of $17 \pm 10 \mathrm{nmol} \mathrm{m}^{-2} \mathrm{~s}^{-1}$.

Consequently, the objectives of this study were to:

(1) Use a new dynamic chamber design to reduce measurement artifacts to clarify the influence of crop plants on atmospheric $\mathrm{CH}_{4}$.

(2) Explore whether nitrogen fertilization changes the magnitude or direction of $\mathrm{CH}_{4}$ plant flux.

(3) Examine the regional $\mathrm{CH}_{4}$ budget using a top-down approach involving $\mathrm{CH}_{4}$ concentration and gradient measurements on a tall tower and examine the relative role of agricultural plants in the regional budget.

\section{Materials and methods}

\section{Research site}

The field experiment was conducted at the University of Minnesota Outreach, Research and Education Park. The research site is located $20 \mathrm{~km}$ south of Minneapolis. The plant flux measurement was made in a field of a soybean 
Table 1 Summary of observed $\mathrm{CH}_{4}$ flux from corn (Zea mays). For unit conversion, we assume a biomass value of $1,652 \mathrm{~g} \mathrm{~m}^{-2}$. DOY Day of year

\begin{tabular}{|c|c|c|c|c|c|}
\hline Reference & Light type & $\begin{array}{l}\text { Light intensity } \\
\left(\mathrm{W} \mathrm{m}^{-2}\right)\end{array}$ & $\begin{array}{l}\mathrm{CH}_{4} \text { background } \\
\text { concentration (ppbv) }\end{array}$ & $\begin{array}{l}\text { Intact/ } \\
\text { detached }\end{array}$ & $\begin{array}{l}\mathrm{CH}_{4} \text { flux } \\
\left(\mathrm{nmol} \mathrm{m}^{-2} \mathrm{~s}^{-1}\right)\end{array}$ \\
\hline \multirow[t]{2}{*}{ Beerling et al. 2008} & Lamp & 152 & 59 & Intact & $0.06 \pm 0.57$ \\
\hline & Dark & 0 & 59 & Intact & $0.14 \pm 1.15$ \\
\hline Dueck et al. 2007 & Lamp & $65 / 130$ & 2,100 & Intact & $0.80 \pm 1.03$ \\
\hline $\begin{array}{l}\text { Kirschbaum and } \\
\text { Walcroft } 2008\end{array}$ & Lamp & 1 & 0 & Intact & $-0.007 \pm 0.032$ \\
\hline \multirow[t]{2}{*}{ Nisbet et al. 2009} & Lamp & 39 & $1,984 \pm 6$ & $\begin{array}{l}\text { Detached } \\
\text { leaves }\end{array}$ & $-0.43 \pm 0.49$ \\
\hline & Lamp & 39 & $2,021 \pm 5$ & $\begin{array}{l}\text { Detached } \\
\text { leaves }\end{array}$ & $0.74 \pm 2.45$ \\
\hline \multirow[t]{2}{*}{ Keppler et al. 2006} & Sunlight & - & 0 & Intact & $11(6-17)$ \\
\hline & Dark & 0 & 0 & Intact & $3(1-6)$ \\
\hline \multirow[t]{2}{*}{ Vigano et al. 2008} & UV lamp & 49 & Ambient or 0 & $\begin{array}{l}\text { Detached } \\
\text { (fresh) }\end{array}$ & 1.4 \\
\hline & UV lamp & 49 & Ambient or 0 & $\begin{array}{l}\text { Detached } \\
\text { (dry) }\end{array}$ & 0.7 \\
\hline \multirow[t]{2}{*}{ This paper } & $\begin{array}{l}\text { Sunlight (with } 10 \% \mathrm{UV} \\
\text { reduction) }\end{array}$ & Ambient & Ambient & Intact & $0.11 \pm 0.06($ DOY $201-218)$ \\
\hline & Dark & 0 & Ambient & Intact & $-0.13 \pm 0.12($ DOY $201-218)$ \\
\hline
\end{tabular}

(Glycine max)-corn (Zea mays) rotation management that is characteristic of the Upper Midwest (Griffis et al. 2005). The soil is a Waukegan silt loam about $0.5-1.8 \mathrm{~m}$ thick, which is underlain by sand and gravel. This field was converted from a prairie to agriculture 130 years ago (Griffis et al. 2005). The land management techniques applied at this site are typical for the region. In the 2008 soybean phase, no fertilizer was applied, except in a small area that was reserved for the fertilizer treatment/experiment. In the 2009 corn phase, fertilizer in the form of anhydrous ammonia was applied at a rate of $112 \mathrm{~kg} \mathrm{~N} \mathrm{ha}^{-1}$ on 15 April [day of year (DOY) 106] except for the zone reserved for non-fertilization treatment.

In the 2008 soybean phase, three soybean plants were selected from three random plots for flux measurements. In the middle of the growing season (10 July, DOY 192), three additional plots of $1 \mathrm{~m}$ radius were treated with fertilizer (24-8-16, NPK; Scotts Miracle-Gro, Marysville, $\mathrm{OH}$ ) at a rate of $500 \mathrm{~kg} \mathrm{~N} \mathrm{ha}^{-1}$. The fertilizer intensity was the upper limit of the growing season total $\mathrm{N}$ application rate found in the literature. The flux measurement was carried out on one plant in the center of each fertilization plot. The chamber measurements started on DOY 160 and ended on DOY 225. The plant density was 30 plants $\mathrm{m}^{-2}$.

In the 2009 corn phase, measurements were made on three corn plants in three random plots. To test the effect of fertilization, a buffer strip $(8 \mathrm{~m} \times 30 \mathrm{~m})$ was excluded from fertilization. Three unfertilized corn plants chosen from three random plots within the strip were also measured. The chamber measurement started on DOY 147 and ended on DOY 218. The plant density was 8.1 plants $\mathrm{m}^{-2}$.
The tall tower $(244 \mathrm{~m})$ facility is located $3 \mathrm{~km}$ southeast of the soybean/corn field (Griffis et al. 2010). A footprint analysis using the STILT model (Lin et al. 2003) during the tall tower observation period (DOY 243-269, 2009) revealed that $66 \%$ of the tower footprint was cropland.

\section{Measurement with plant chambers}

A steady-state flow-through chamber system was used to measure the plant $\mathrm{CH}_{4}$ and $\mathrm{CO}_{2}$ fluxes (Fig. 1). It consisted of plant chambers of varying sizes, a cooling apparatus, and gas analyzers. To accommodate plant growth, we used three chamber sizes: small $(25 \mathrm{~cm} \times 25 \mathrm{~cm} \times 25 \mathrm{~cm})$, medium $(50 \mathrm{~cm} \times 50 \mathrm{~cm} \times 50 \mathrm{~cm})$, and large $(50 \mathrm{~cm} \times 50 \mathrm{~cm} \times$ $150 \mathrm{~cm}$ ). Two fans positioned near the top of the chamber and pointed at downward-facing angles promoted mixing inside. The small and medium chambers were made of transparent plexiglass with minimum light attenuation $[<8 \%$ in the photosynthetically active radiation (PAR) waveband, and $<10 \%$ in the UV waveband]. The chamber was seated on a metal base frame $5 \mathrm{~cm}$ above the soil surface. Two plexiglass plates were placed on the base, allowing one plant stem to pass through a hole at the center. The chamber base was not sealed; instead, ambient air entered the chamber from the perimeter of the base, and the $\mathrm{CH}_{4}$ and $\mathrm{CO}_{2}$ concentrations in the air were sampled and measured continuously. The large chamber was used when the corn plants were taller than $1.5 \mathrm{~m}$. It consisted of the medium chamber with the base removed and a skirt made of transparent polyethylene. The plexiglass chamber rested on 
a metal frame whose height was adjustable from $1 \mathrm{~m}$ to $1.7 \mathrm{~m}$. The polyethylene skirt was attached to the sides of the plexiglass chamber using strong bonding tape, and the bottom was tied loosely to the base of the plant allowing air to enter from the base of the plant.

A cooling system kept the chamber temperature consistent with ambient conditions by circulating chilled water through a heat exchanger inside the chamber. Control of the cooling was achieved by adjusting the water circulation rate. Temperature was monitored using thermocouples inside and outside the chamber. The difference between the chamber temperature and the ambient temperature was maintained to within $\pm 3{ }^{\circ} \mathrm{C}$.

The chamber system could accommodate only one plant at a time. Therefore, we were limited to measuring one plant per day. The system was rotated sequentially among the replicated plots. One complete rotation took 6-7 days. The cooling system permitted continuous measurement throughout the daytime and nighttime without overheating in full sunlight. This arrangement was a compromise between capturing temporal variations at the diurnal and seasonal time scales and spatial variations among the replicates.

Two analyzers were used to measure the $\mathrm{CO}_{2}, \mathrm{~N}_{2} \mathrm{O}$, and $\mathrm{CH}_{4}$ mixing ratios of the inlet and outlet air streams of the chamber. The base flow rate of the outlet was maintained at $35 \mathrm{~L} \mathrm{~min}^{-1}, 47 \mathrm{~L} \mathrm{~min}^{-1}$, and $51 \mathrm{~L} \mathrm{~min}^{-1}$ for the small, medium, and large chambers, respectively. The flow rate was set relatively high to reduce the impact of the strong $\mathrm{CO}_{2}$ depletion inside the chamber during the daytime. The inlet air was sampled with a tube with evenly distributed holes attached to the outside perimeter of the bottom of the chamber. Air entered from the unsealed bottom of the chamber as described and was pumped out (outlet air) at the base flow rates by a tube placed vertically inside the chamber (Fig. 1). This tube had small sampling holes distributed evenly from the bottom to the top to avoid the artifact of the concentration gradient inside the chamber. All sampling tubes were made of high-density polyethylene material. Two subsamples were drawn from the inlet and outlet tubes for the $\mathrm{CH}_{4} / \mathrm{N}_{2} \mathrm{O}$ and $\mathrm{CO}_{2} / \mathrm{H}_{2} \mathrm{O}$ measurements, at flow rates of $180 \mathrm{~mL} \mathrm{m^{-1 }}$ and $1.0 \mathrm{~L} \mathrm{~min}{ }^{-1}$, respectively. A tunable diode laser analyzer (TDL, model TGA 100A, Campbell Scientific, Logan, UT) was used to measure the $\mathrm{CH}_{4}$ and $\mathrm{N}_{2} \mathrm{O}$ mixing ratios. The laser temperature was optimized and maintained at $90.80 \mathrm{~K}$ in 2008 and $91.30 \mathrm{~K}$ in 2009 , while the temperature of the detectors was maintained at $135.5 \mathrm{~K}$ using liquid nitrogen. The sample cell pressure was maintained at $36 \mathrm{mb}$. The TDL was plumbed to a four-port manifold that used a switching sequence in the order of inlet, outlet, calibration zero, and calibration span, with $20 \mathrm{~s}$ spent on each port and the first $10 \mathrm{~s}$ after each switching omitted from the analysis. The $\mathrm{CO}_{2}$ and $\mathrm{H}_{2} \mathrm{O}$ mixing ratios were measured using an infrared gas analyzer (IRGA; LI6262, LI-COR, Lincoln, NE). This analyzer was switched between the inlet and outlet air flows every $1 \mathrm{~min}$, with the first $30 \mathrm{~s}$ after each switching excluded from the computation of the average concentrations. The analyzers were housed in an air-conditioned hut to minimize the impact of temperature fluctuations on the measurements. The $\mathrm{CH}_{4}$ span calibration standard had a mixing ratio of $2.2 \mathrm{ppmv}$ (accuracy $\pm 5 \%$ ). The IRGA was calibrated manually with a standard $\mathrm{CO}_{2}$ gas $(391.03 \pm 0.03$ ppmv $)$ and a dew point generator (model LI-610, LI-COR) at the beginning of each field season.

The difference in mixing ratios between the chamber inlet and outlet was used to determine the plant flux as,

$\mathrm{F}_{\mathrm{a}}=\left(\mathrm{C}_{\mathrm{o}}-\mathrm{C}_{\mathrm{i}}\right) \frac{\mathrm{P}_{\mathrm{a}} \mathrm{QD}}{\mathrm{RT}}$

where $F_{\mathrm{a}}$ is the flux expressed on the ground area basis

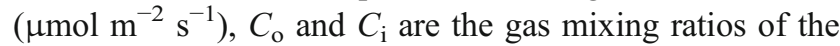
outlet and inlet samples, respectively, $P_{\mathrm{a}}$ is the ambient air pressure, $Q$ is the air flow rate through the chamber, $D$ is the plant density (plants $\mathrm{m}^{-2}$ ), $R$ is the ideal gas constant, and $T$ is the temperature. This calculation was performed at halfhour intervals for three gases $\left(\mathrm{CO}_{2}, \mathrm{CH}_{4}\right.$, and $\left.\mathrm{N}_{2} \mathrm{O}\right)$. The analysis of the $\mathrm{N}_{2} \mathrm{O}$ data will be reported later.

\section{Tall tower gradient measurement}

From 30 August to 25 September 2009 (DOY 243-269), the TDL and IRGA analyzers were deployed at the tall tower to explore the behaviors of the $\mathrm{CH}_{4}$ and $\mathrm{CO}_{2}$ mixing ratios in the atmospheric boundary layer. Air was drawn from the $200 \mathrm{~m}$ and $3 \mathrm{~m}$ height at a flow rate of $1.3 \mathrm{~L} \mathrm{~min}^{-1}$ and $0.9 \mathrm{~L} \mathrm{~min}^{-1}$, respectively, through two tubes (ID $0.96 \mathrm{~cm}$ ) to the analyzers housed in a temperature-controlled building at the base of the tower (Griffis et al. 2010). A portion of the flow (180 ml min $\mathrm{m}^{-1}$ for TDL and $0.6 \mathrm{~L} \mathrm{~min}^{-1}$ for IRGA) was subsampled by the analyzers. The TDL air sampling sequence included $200 \mathrm{~m}, 3 \mathrm{~m}$, calibration zero, and calibration span. Each sample lasted for $30 \mathrm{~s}$. The data following the first $15 \mathrm{~s}$ of valve switching were excluded to avoid using residual air from the previous sample when calculating the mean concentrations. The IRGA was used to analyze the $200 \mathrm{~m}$ and $3 \mathrm{~m}$ concentrations sequentially with a sample interval of $1 \mathrm{~min}$.

We calculated the landscape-scale $\mathrm{CH}_{4}$ flux using the modified Bowen ratio method (MBR) (Meyers et al. 1996; Werner et al. 2003). This method is based on the assumption that the scalar quantities are transferred indiscriminately by turbulent eddies in the atmospheric boundary layer. Under this assumption, the $\mathrm{CH}_{4}$ flux is given by

$\mathrm{F}_{2}=\mathrm{F}_{1} \frac{\partial \mathrm{c}_{2} / \partial \mathrm{z}}{\partial \mathrm{c}_{1} / \partial \mathrm{z}}$ 
Fig. 1 Schematic diagram and photograph of the plant chamber system

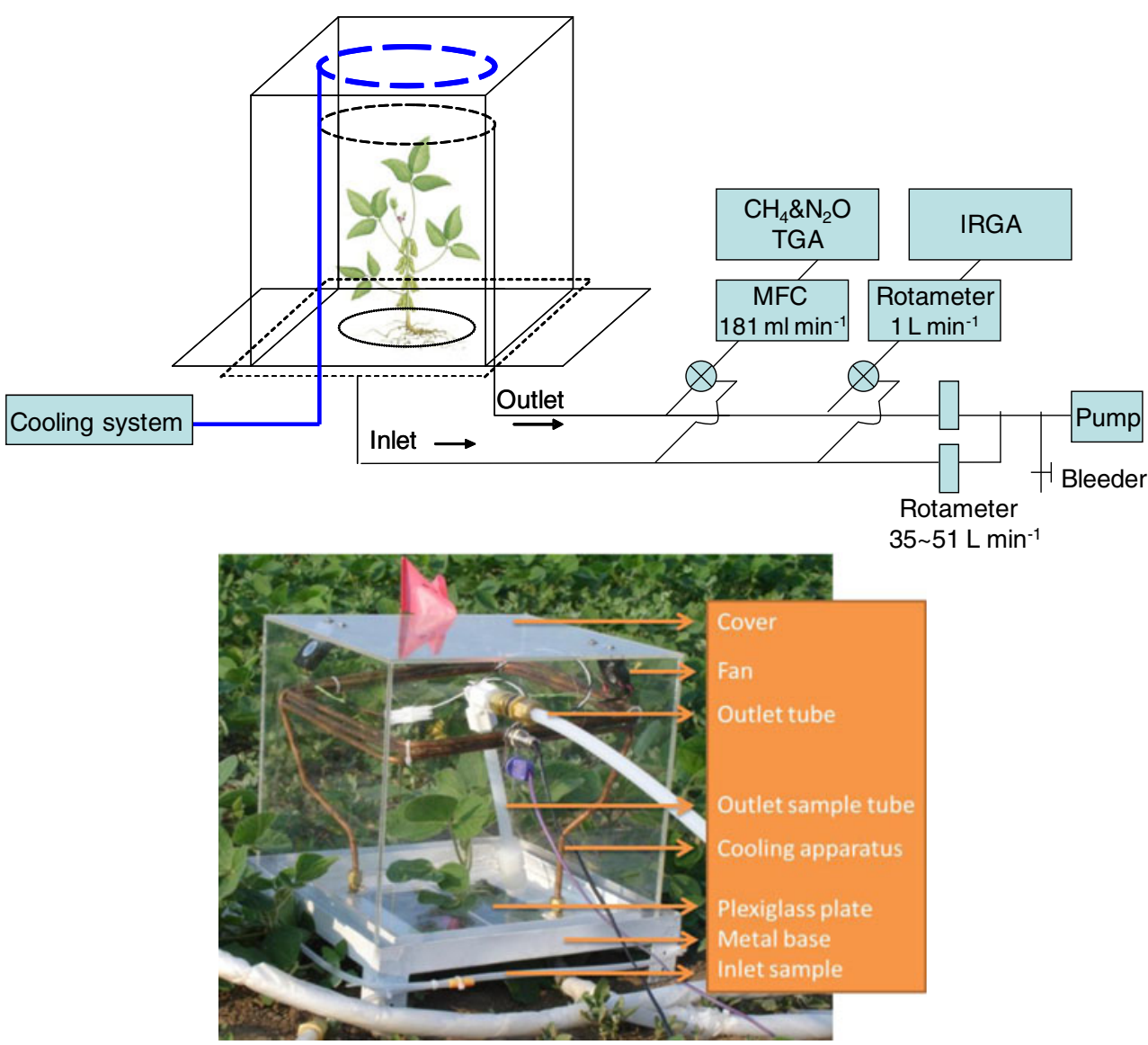

where $F_{2}$ is the $\mathrm{CH}_{4}$ flux, $F_{1}$ is the $\mathrm{CO}_{2}$ flux, $\partial c_{2} / \partial z$ is the $\mathrm{CH}_{4}$ gradient, and $\partial c_{1} / \partial z$ is the $\mathrm{CO}_{2}$ gradient. The $\mathrm{CO}_{2}$ flux was measured using the eddy covariance at $100 \mathrm{~m}$ at the tall tower (Griffis et al. 2010).

\section{Supporting measurements}

At the chamber measurement site, standard micrometeorological and eddy flux variables were measured at half-hour intervals, including variables relevant to this study such as $\mathrm{CO}_{2}$ flux, soil moisture, air temperature, solar radiation, and precipitation. The same set of measurements was made simultaneously in an adjacent field with a soybean-corn rotation schedule opposite that of the main field. Details of these measurements can be found in Baker and Griffis (2005) and Bavin et al. (2009).

\section{Results}

Leaf area index and biomass

In the literature, plant $\mathrm{CH}_{4}$ flux is often expressed based on unit dry biomass weight and unit leaf area. To facilitate comparison with the published results, we measured the leaf area index (LAI) and the plant biomass. During the experimental period, we randomly sampled five plants in the fertilized zone and the unfertilized zone every week, measured the leaf area, dried the plant samples in an oven (temperature maintained at $60{ }^{\circ} \mathrm{C}$ ) for 1 week, and then measured the dry weight.

The unfertilized soybean plants had a maximum LAI of $3.3 \mathrm{~m}^{2} \mathrm{~m}^{-2}$ on DOY 224 (11 August) and a dry weight of 14 gdw (grams dry weight) plant ${ }^{-1}$ on DOY 231 (18 August). The LAI and the dry weight for the fertilized soybean plants, measured at the end of the experiment on DOY 242, were $1.7 \mathrm{~m}^{2} \mathrm{~m}^{-2}$ and $22.6 \mathrm{gdw}$ plant ${ }^{-1}$, respectively. The maximum LAI of the unfertilized and fertilized corn plants during the 2009 season was $3.5 \mathrm{~m}^{2} \mathrm{~m}^{-2}$ and $5.6 \mathrm{~m}^{2} \mathrm{~m}^{-2}$, respectively, and the maximum dry weight was $181 \mathrm{gdw}$ plant $^{-1}$ and $231 \mathrm{gdw}$ plant $^{-1}$, respectively. The unfertilized soybean plants grew to a maximum height of $0.40 \pm 0.01 \mathrm{~m}$ while the fertilized ones reached $0.53 \pm 0.13 \mathrm{~m}$ at the end of the experiment. The maximum height of the unfertilized and fertilized corn plants was $1.84 \pm 0.30 \mathrm{~m}$ and $2.23 \pm 0.04 \mathrm{~m}$, respectively.

Zero gradient test and chamber blank tests

To quantify the precision of the $\mathrm{CH}_{4}$ concentration measurements and to determine the detection limits of the chamber 
system, we conducted a zero gradient test and three blank tests on each chamber.

The zero gradient test was carried out by co-locating two sample inlets at the same height (about $1 \mathrm{~m}$ above ground) to assess the difference between the two inlets resulting from potential sample artifacts. The results from this test indicate that the measurement precision for the half-hourly averaged $\mathrm{CO}_{2}$ and $\mathrm{CH}_{4}$ concentration was 0.15 ppmv and $1.25 \mathrm{ppbv}$ (the standard deviation $\sigma$ of the zero-gradient test result), respectively. The concentration difference between the two inlets was 0.04 ppmv and -0.05 ppbv and therefore not significantly different from 0 (Student's $t$-test at the $5 \%$ significance level for both gases).

Three blank tests were carried out on each chamber, with each test lasting $24 \mathrm{~h}$, by placing the chamber in the field without including any plants. The half-hour averaged concentration difference resulting from the blank test was not significantly different from 0 (Fig. 2), indicating that there was no significant bias in the chamber flux measurement. The chamber flux detection limit was defined as three times the blank standard deviation for each chamber size. The blank test flux was calculated with Eq. 1 by assuming a plant density of 30 plants $\mathrm{m}^{-2}$ and 8.1 plants $\mathrm{m}^{-2}$ for soybean and corn, respectively. As a result, the detection limit of $\mathrm{CH}_{4}$ flux for the small and medium chambers was $0.40 \mathrm{nmol} \mathrm{m}^{-2} \mathrm{~s}^{-1}$ and $0.21 \mathrm{nmol} \mathrm{m}^{-2} \mathrm{~s}^{-1}$ for soybean and $0.11 \mathrm{nmol} \mathrm{m}^{-2} \mathrm{~s}^{-1}$ and $0.06 \mathrm{nmol} \mathrm{m}^{-2} \mathrm{~s}^{-1}$ for corn, respectively. The different detection limits between corn and soybean were due to the different plant densities. The large chamber was used only for corn plants, and the $\mathrm{CH}_{4}$ flux detection limit was $0.83 \mathrm{nmol} \mathrm{m}^{-2} \mathrm{~s}^{-1}$. The small and the medium chambers had better precision than the large chamber.

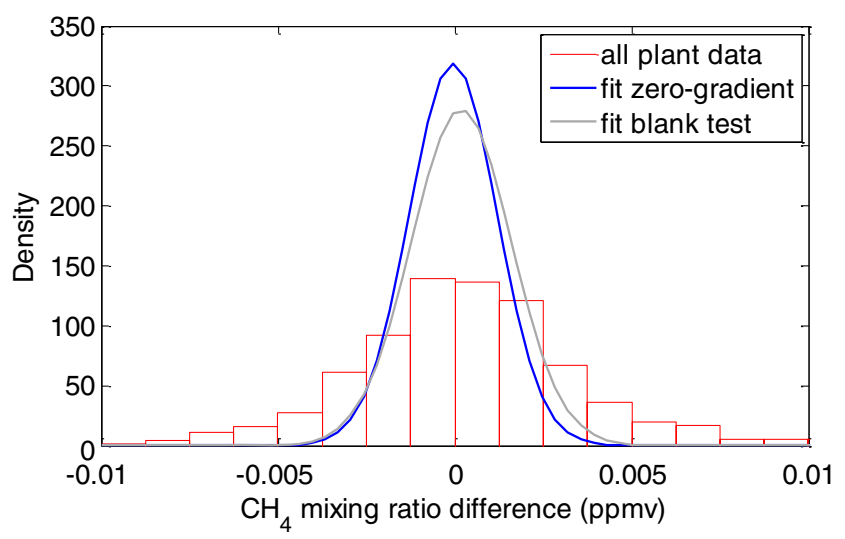

Fig. 2 Distribution of the half-hour averaged $\mathrm{CH}_{4}$ mixing ratio difference between two sample points during a 24-h chamber measurement period taken in 2009. The blue and grey lines are the normal distribution curves of the zero-gradient test and the blank test, respectively. The red bars are the mixing ratio difference measured when the plant was enclosed in the chamber
Even though reducing the flow rate of the sampling system can improve the detection limit, reducing the flow will result in large $\mathrm{CO}_{2}$ depletion inside the chamber during the daytime. Note that if we applied the flow rate that was used at the beginning of the growing season $\left(35 \mathrm{~L} \mathrm{~min}^{-1}\right)$ to the middle of the growing season, the $\mathrm{CO}_{2}$ concentration inside the chamber would be more than 100 ppmv lower than the ambient value because of the plants' strong photosynthetic activity. Consequently, we adjusted the flow rate to reduce the artifact of $\mathrm{CO}_{2}$ depletion. As a result, $35 \%$ of the measured $\mathrm{CH}_{4}$ concentration difference, when plants were present in the chamber, was between $-1.25 \mathrm{ppbv}$ and 1.25 ppbv ( $\pm 1 \sigma$ of the zero gradient test), suggesting that the plant flux was too small to be resolved with this method (Fig. 2). However, $65 \%$ of the flux data was detected with relatively high confidence, and the mean $\mathrm{CH}_{4}$ flux of the three duplicates throughout the corn season was $0.085 \pm$ $0.056 \mathrm{nmol} \mathrm{m}^{-2} \mathrm{~s}^{-1}$, i.e., significantly higher than 0 (with a $5 \%$ significance level).

\section{Plant $\mathrm{CO}_{2}$ flux}

To evaluate the validity of the chamber approach, the plant $\mathrm{CO}_{2}$ flux measured with the chamber approach was compared with the plant flux estimated from the eddy covariance and soil chamber data. Here, we assume that the plant flux can be estimated as the difference between the net ecosystem $\mathrm{CO}_{2}$ exchange (NEE) and soil respiration. In 2009, the NEE was measured in the middle of the G21 cornfield by an eddy covariance system (EC), and soil respiration was measured using three soil chambers located within the same field. The $\mathrm{CO}_{2}$ flux measured from the plant chamber and that derived from the NEE showed that (1) the flux measured with the plant chambers captured the diurnal pattern of plant activity (Fig. 3); (2) the flux measured with the plant chamber was linearly correlated with that estimated by the EC and soil flux $(P<0.01)$, and the fitted line was close to the 1:1 line (Fig. 4).

\section{Plant $\mathrm{CH}_{4}$ flux}

Figure 5 shows the plant flux observed during the midday (10:00-16:00 LST) and midnight (22:00-04:00 LST) periods over the two growing seasons. The flux exhibited some diurnal variations, with slightly positive values during the day and negative values during the night. Throughout the soybean growing season, $91 \%$ of the midday average flux values were positive, with a maximum emission rate of $1.31 \mathrm{nmol} \mathrm{m} \mathrm{m}^{-2} \mathrm{~s}^{-1}$. The flux did not simply increase as biomass accumulated. In comparison, $86 \%$ of the midnight flux values were negative, and the uptake signal appeared stronger later in the growing season with a maximum uptake rate of $-4.38 \mathrm{nmol} \mathrm{m}^{-2} \mathrm{~s}^{-1}$. During the corn season, $90 \%$ of 

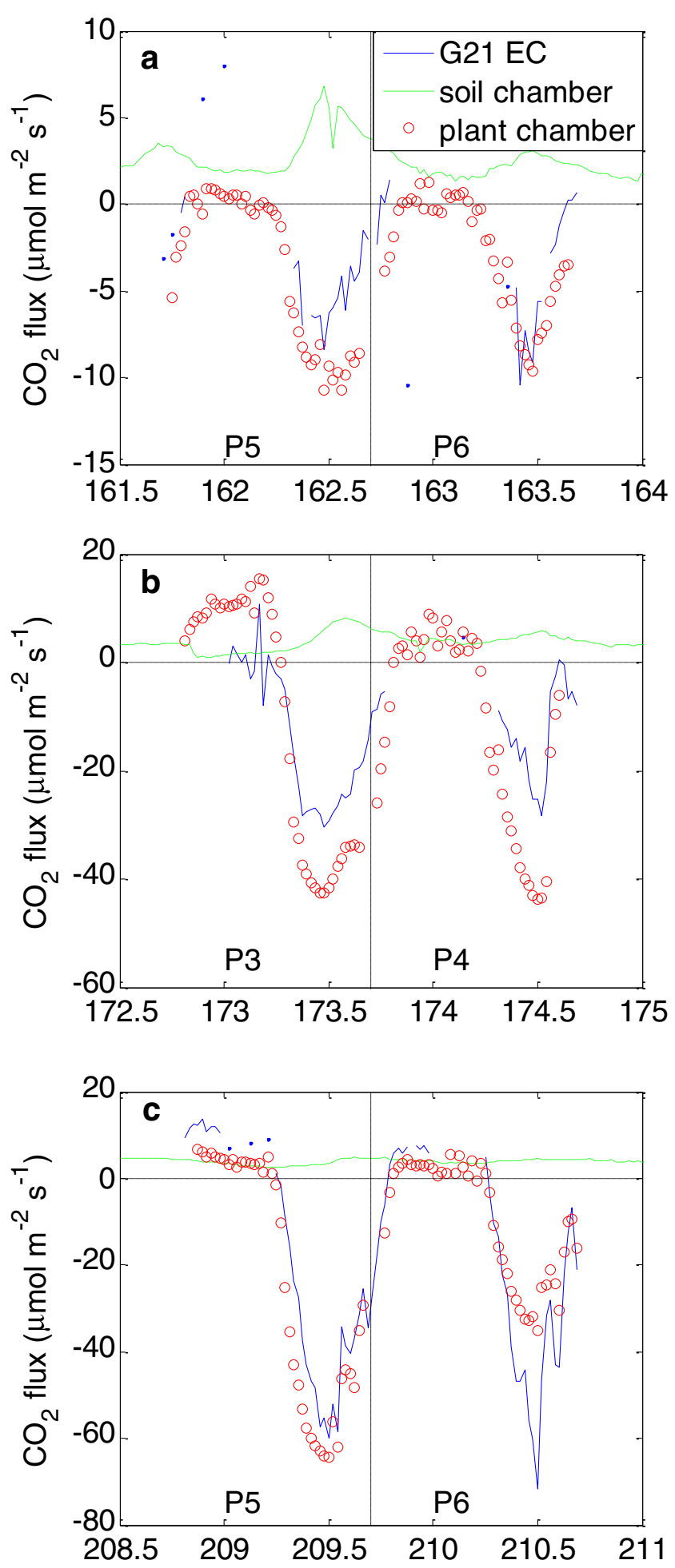

Fig. 3 Half-hour averaged $\mathrm{CO}_{2}$ flux measured with the eddy covariance system in the cornfields (blue lines), soil chambers (green dashed lines), plant chambers (red circles). a Small chamber, b medium chamber, c large chamber. P3-P6 means sampled corn plant 3-6. P3 and P5 were fertilized, while P4 and P6 were not fertilized. The measurement period was chosen according to the availability of the chamber measurement data and the G21 eddy covariance measurement data

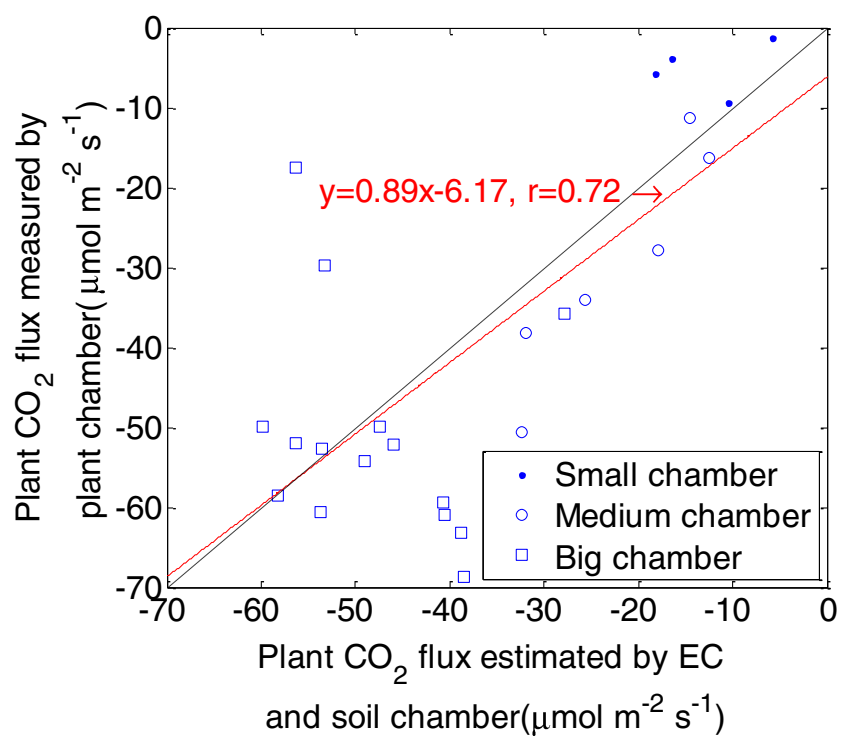

Fig. 4 Comparison of the midday (10:00-16:00) averaged $\mathrm{CO}_{2}$ flux estimated with the eddy covariance (EC)-soil and measured with the plant chamber

the midday averages were positive, $76 \%$ of the midnight averages were negative, and the daytime fluxes peaked at the time when the biomass growth rate was the greatest. The maximum emission rate and the uptake rate for corn were $2.21 \mathrm{nmol} \mathrm{m}^{-2} \mathrm{~s}^{-1}$ and $-2.55 \mathrm{nmol} \mathrm{m} \mathrm{s}^{-1}$, respectively.

The flux values shown in Fig. 5 are much lower than the values reported by Keppler et al. (2006), who estimated that intact plants emit $\mathrm{CH}_{4}$ at a rate of $370 \mathrm{ng}$ $\mathrm{CH}_{4} \mathrm{gdw}^{-1} \mathrm{~h}^{-1}$, with a range of variations of 200 $600 \mathrm{ng} \mathrm{CH}_{4} \mathrm{gdw}^{-1} \mathrm{~h}^{-1}$ under sunlight and $120 \mathrm{ng}$ $\mathrm{CH}_{4} \mathrm{gdw}^{-1} \mathrm{~h}^{-1}$ (range 30-210 ng CH $\mathrm{gdw}^{-1} \mathrm{~h}^{-1}$ ) in the dark. Keppler et al. (2006), measured $\mathrm{CH}_{4}$ emissions from intact plant (including the roots) while the method in our study isolated the $\mathrm{CH}_{4}$ flux of the aboveground section of the plant. However, Keppler et al.'s emission rate is determined by the amount of $\mathrm{CH}_{4}$ emitted per unit of dry weight per hour, and they did not distinguish a separate emission rate for leaves and roots. As a result, we multiplied Keppler et al.'s emission rates with the dry weight for the aboveground section of plant measured throughout the growing season and the plant density to obtain the flux in units of nmol m $\mathrm{m}^{-2} \mathrm{~s}^{-1}$, and compared the results with our observations (Fig. 5). In the comparison, the daytime and nighttime flux from Keppler et al. was determined by the emission rate observed with and without sunlight, and the same method was used in Keppler et al. (2006) to estimate the annual $\mathrm{CH}_{4}$ production. Our results were below the lower limit of Keppler et al.'s estimate except at the beginning of the growing season when the plants were very small. Furthermore, for nighttime periods, Keppler et al.'s values were positive while our observed flux 
Fig. 5 Midday (10:00-16:00 LST) and midnight (22:0004:00 LST) plant fluxes in the soybean fields (a, c) and the cornfields $(\mathbf{b}, \mathbf{d})$ throughout the growing season: red filled symbols fertilized plant flux; blue open symbols unfertilized plant flux; circles, triangles, squares fluxes measured with the small chamber, the medium chamber, and the large chamber; black lines $\mathrm{CH}_{4}$ flux suggested by Keppler et al. (2006); green lines boundary of Keppler et al.'s estimates
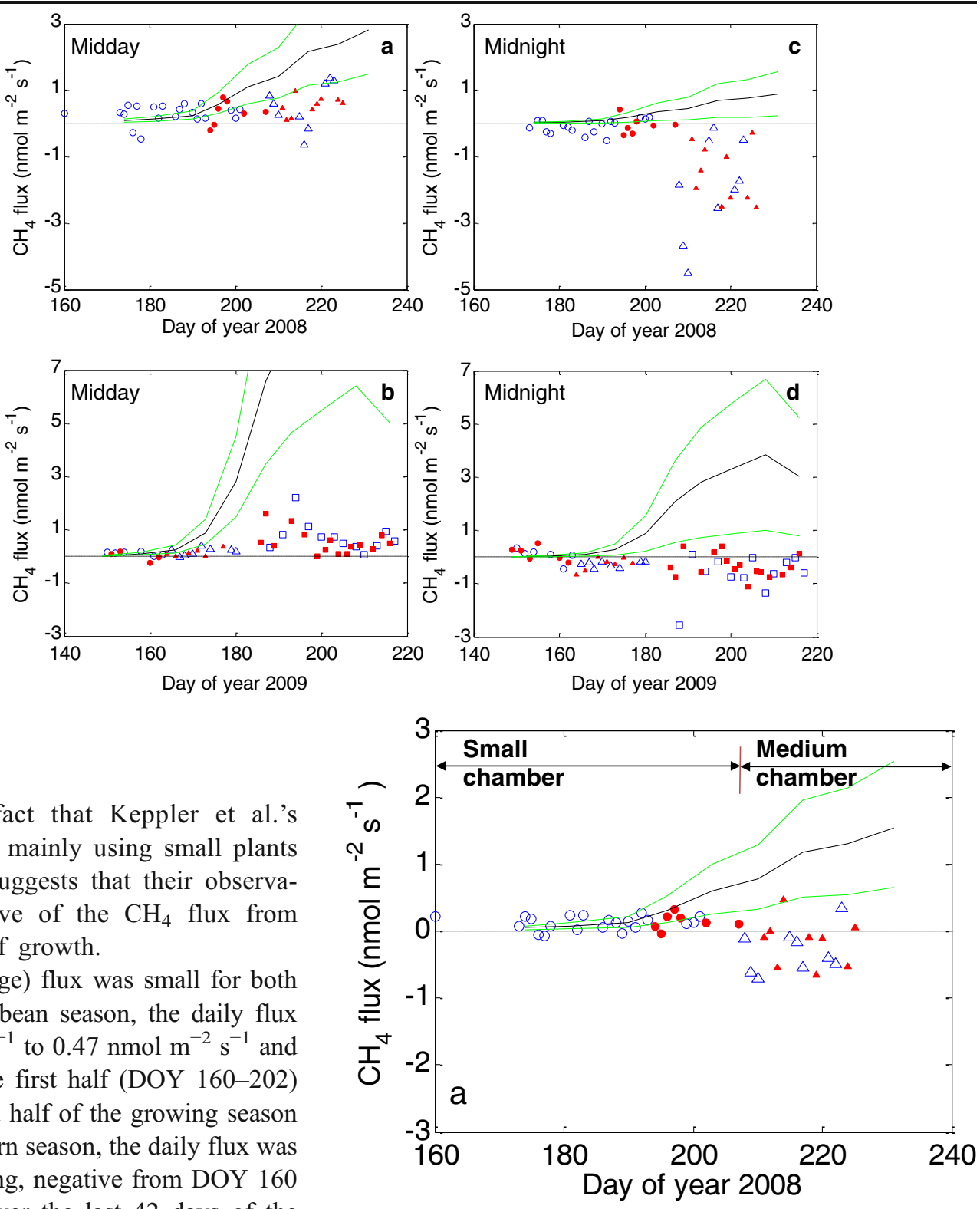

was mostly negative. The fact that Keppler et al.'s emission rate was determined mainly using small plants in their early growth stage, suggests that their observation may not be representative of the $\mathrm{CH}_{4}$ flux from various phenological stages of growth.

The daily mean (24-h average) flux was small for both crops (Fig. 6). During the soybean season, the daily flux ranged from $-0.70 \mathrm{nmol} \mathrm{m}^{-2} \mathrm{~s}^{-1}$ to $0.47 \mathrm{nmol} \mathrm{m}^{-2} \mathrm{~s}^{-1}$ and was mostly positive during the first half (DOY 160-202) and negative during the second half of the growing season (DOY 207-225). During the corn season, the daily flux was slightly positive at the beginning, negative from DOY 160 to 175 , and mostly positive over the last 42 days of the measurement period. Relatively large emissions (up to $1.08 \mathrm{nmol} \mathrm{m}^{-2} \mathrm{~s}^{-1}$ ) were observed near the end of the measurement period in 2009. These daily values were much lower than those reported by Keppler et al. (2006).

In the discussion above, we did not distinguish fertilized and unfertilized plots. Figure 7 shows the fertilization effects on the daily, midday, and midnight $\mathrm{CH}_{4}$ and $\mathrm{CO}_{2}$ fluxes throughout the growing season. For each flux, we paired the data with and without fertilization treatment, and used a Student's $t$-test to examine the significance of the fertilization effect. The result shows that fertilization did not affect $\mathrm{CH}_{4}$ fluxes in any of the three periods $(P>0.05)$. Fertilization increased the midday corn uptake of $\mathrm{CO}_{2}(P<$ 0.05 ), and the daily corn $\mathrm{CO}_{2}$ flux increased significantly as well $(P<0.05)$. However, the nighttime $\mathrm{CO}_{2}$ emission from corn was not significantly affected. The fertilization effect on the daily and midday soybean $\mathrm{CO}_{2}$ fluxes was not as

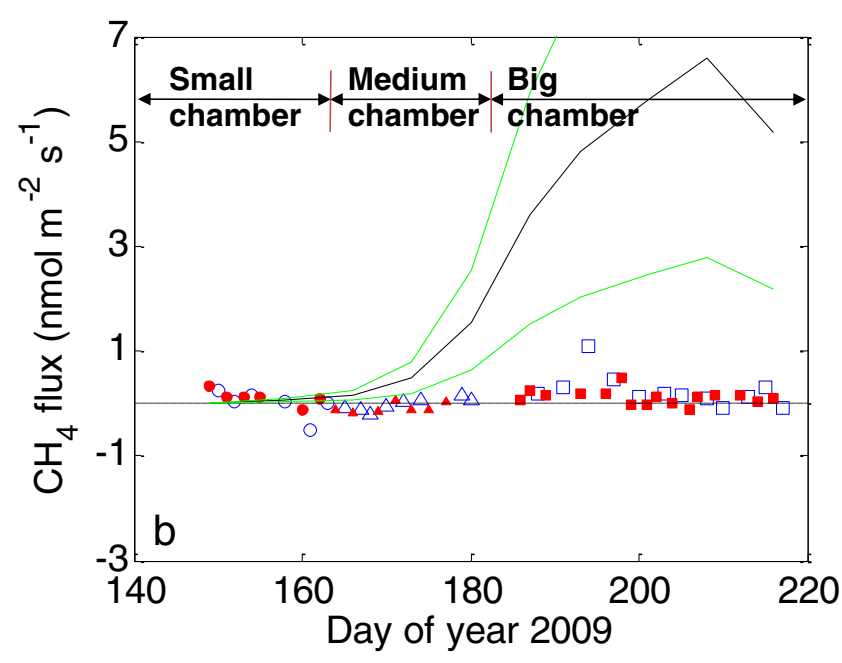

Fig. 6 As in Fig. 5 except for the daily average plant $\mathrm{CH}_{4}$ flux in soybean fields (a) and cornfields (b) 
Fig. 7 Daily, midday (10:0016:00 LST), and midnight (22:00-04:00 LST) fluxes averaged over the soybean (a, b) and (c, b) corn growing seasons. Error bars Standard deviations of the three replicate plants. NS Difference between fertilized and unfertilized plant fluxes insignificant $(P>0.05)$
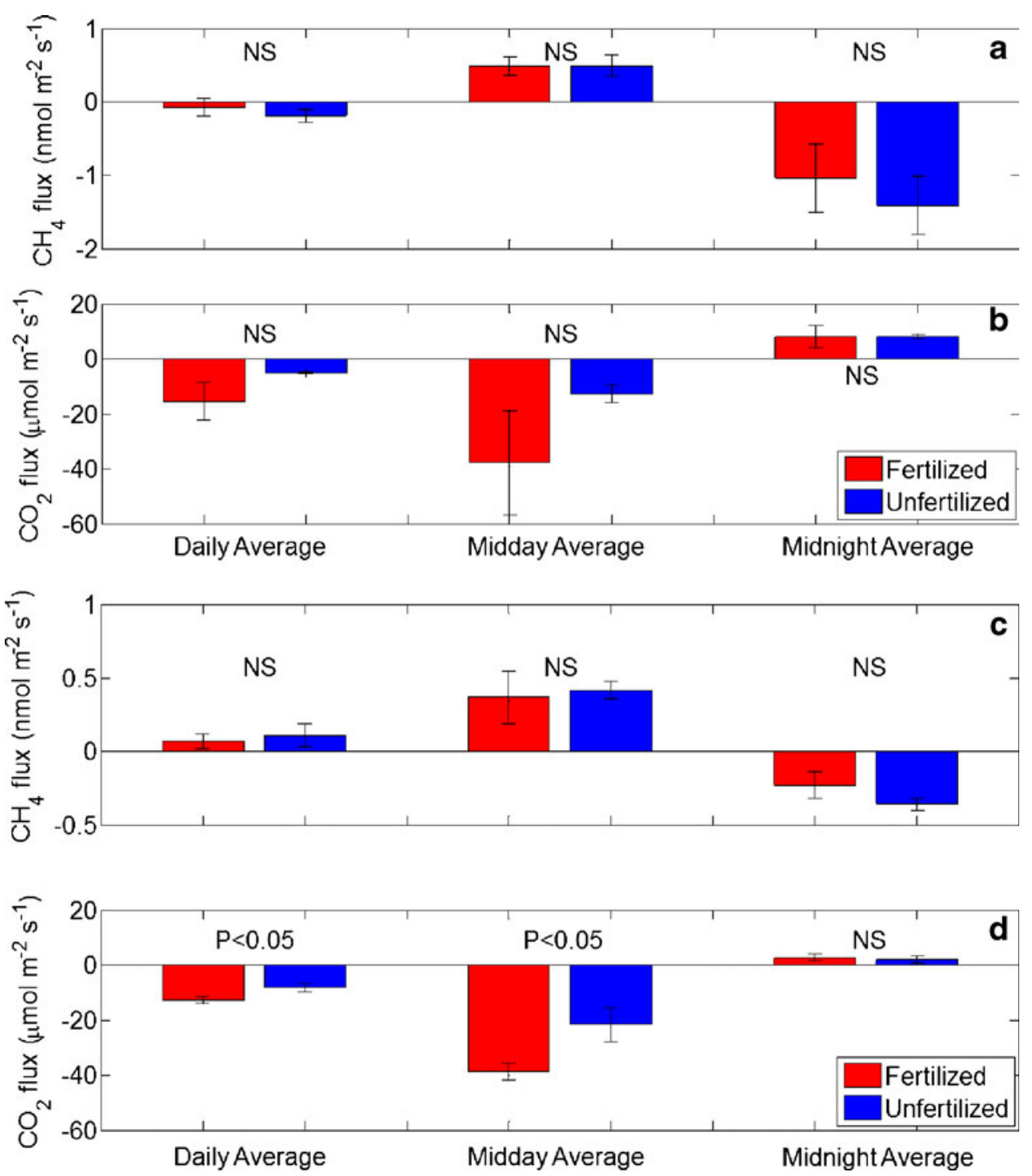

significant as for corn ( $P=0.06$ and 0.09 , respectively), and the midnight flux was not significantly affected by fertilization.

Table 2 summarizes the linear correlation between plant $\mathrm{CH}_{4}$ fluxes and environmental variables, including incident solar radiation, air temperature, soil water content at $10 \mathrm{~cm}$ depth, and soil temperature at $10 \mathrm{~cm}$. These variables were considered in previous studies on plant $\mathrm{CH}_{4}$ emission and uptake (Keppler et al. 2006; Nisbet et al. 2009). These results show that the midday flux of corn and soybean was positively correlated with solar radiation, with $P$-values of 0.004 and 0.08 , respectively. The correlation with other environmental variables was not consistent for soybean and corn. The midday corn $\mathrm{CH}_{4}$ flux was moderately correlated with air temperature, soil water content, and soil temperature, but the soybean $\mathrm{CH}_{4}$ flux was not. Regarding the midnight measurement, corn $\mathrm{CH}_{4}$ flux was negatively correlated only with air temperature, while soybean $\mathrm{CH}_{4}$ flux was weakly correlated only with soil moisture.

The correlation between the $\mathrm{CH}_{4}$ and $\mathrm{CO}_{2}$ fluxes was also tested to examine the potential relations between $\mathrm{CH}_{4}$ flux and the process of photosynthesis and respiration. The analysis shows that $\mathrm{CH}_{4}$ plant flux was negatively correlated with $\mathrm{CO}_{2}$ flux throughout the day for corn and soybean, and that fertilization did not affect this correlation.

Tall tower $\mathrm{CH}_{4}$ observation

The $\mathrm{CH}_{4}$ concentration at $3 \mathrm{~m}$ and $200 \mathrm{~m}$ at the tall tower site exhibited diurnal variations, which suggests that this agriculture-dominated landscape released $\mathrm{CH}_{4}$ at night, but the direction of the daytime flux was not clear (Fig. 8). After 19:00 LST, with the formation of the stable nighttime boundary layer, $\mathrm{CH}_{4}$ accumulated near the ground surface, 
Table 2 Linear correlation of plant $\mathrm{CH}_{4}$ flux with environmental variables and $\mathrm{CO}_{2}$ flux

\begin{tabular}{|c|c|c|c|c|c|c|}
\hline & $n$ & Solar radiation & Air temperature & Soil moisture & Soil temperature & $\mathrm{CO}_{2}$ flux \\
\hline \multicolumn{7}{|l|}{ Corn } \\
\hline Midday flux & 52 & $0.37 * * * *$ & $0.25 * *$ & $-0.36 * * *$ & $0.27 * *$ & $-0.35 * * *$ \\
\hline Midnight flux & 56 & $\mathrm{~N} / \mathrm{A}$ & $-0.30^{* *}$ & 0.09 & 0.05 & $-0.15^{*}$ \\
\hline \multicolumn{7}{|l|}{ Soybean } \\
\hline Midday flux & 46 & $0.21^{*}$ & 0.04 & -0.07 & 0.08 & $-0.21 *$ \\
\hline Midnight flux & 45 & N/A & 0.00 & $0.24 *$ & -0.08 & $-0.72 * * * *$ \\
\hline
\end{tabular}

$*(0.05<P<0.1), * *(0.01<P \leq 0.05), * * *(0.001<P \leq 0.01), * * * *(P \leq 0.001)$, ns $(P>0.1)$

and the $3 \mathrm{~m}$ concentration peaked around 07:00 LST. The peak value varied from day to day, and the average at 07:00 LST was $2.232 \pm 0.291$ ppmv. After sunrise, turbulent motion in the surface layer diluted the $\mathrm{CH}_{4}$-rich air near ground with air from higher altitudes and increased the $\mathrm{CH}_{4}$ concentration at $200 \mathrm{~m}$ above the ground. The concentration at both heights decreased until 16:00 LST, when the concentration at both heights was approximately 1.996 ppmv. These diurnal trends suggest that the surface was a source at night. However, these trends cannot indicate land surface uptake during the daytime because the depletion could also be attributed to the entrainment at the top of the convective boundary layer.

The $\mathrm{CH}_{4}$ and $\mathrm{CO}_{2}$ concentration gradients at night also suggest nighttime release of $\mathrm{CH}_{4}$ by the landscape. The $\mathrm{CH}_{4}$ concentration gradient in the 3 to $200 \mathrm{~m}$ air layer was consistently negative (concentration at $200 \mathrm{~m}<$ concentration at $3 \mathrm{~m})$ at night $\left(-0.62 \pm 0.60 \mathrm{ppbv} \mathrm{m}^{-1}\right)$, similar to the

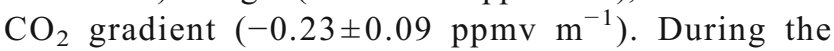

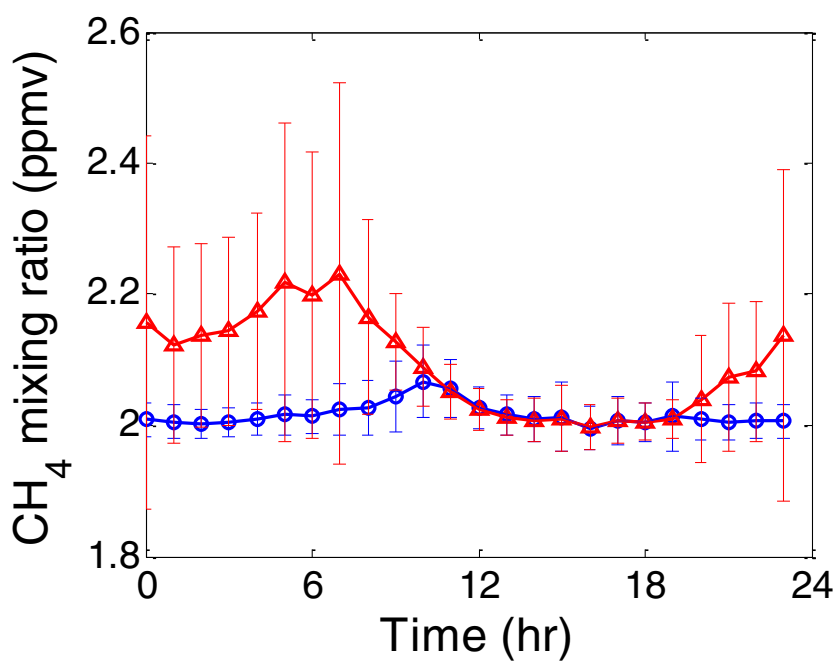

Fig. 8 Diurnal composite of the $\mathrm{CH}_{4}$ mixing ratio at $3 \mathrm{~m}$ and $200 \mathrm{~m}$ above the ground during DOY 243-269, 2009. Red triangles and blue circles are the hourly mean values of the mixing ratio at $3 \mathrm{~m}$ and $200 \mathrm{~m}$, respectively. Error bars Standard deviation of 30-min observations observation period, the midnight (22:00-04:00 LST) average $\mathrm{CH}_{4}$ gradient $\left(\mathrm{G}_{\mathrm{CH} 4}\right)$ was positively correlated to the midnight $\mathrm{CO}_{2}$ gradient $\left(\mathrm{G}_{\mathrm{CO} 2}\right)$ (Fig. 9a). The relation between the two gradients was $\mathrm{G}_{\mathrm{CH} 4}=3.8 \times 10^{-3} \mathrm{G}_{\mathrm{CO} 2}+2.6 \times$ $10^{-4}$ (linear correlation $r=0.54$, number of observations $n=$ $25)$. Due to the strong daytime mixing in the boundary layer, the $\mathrm{CH}_{4}$ and $\mathrm{CO}_{2}$ gradients during midday (10:00-16:00) were very small: the $\mathrm{CH}_{4}$ gradient was $-6.2 \times 10^{-3} \pm 3.0 \times$ $10^{-2} \mathrm{ppbv} \mathrm{m}^{-1}$ (not significantly different from 0 according to a Student's $t$-test with a significance level of $5 \%$ ), and the $\mathrm{CO}_{2}$ gradient was $9.12 \times 10^{-3} \pm 9.97 \times 10^{-3} \mathrm{ppmv} \mathrm{m}^{-1}$.

The $\mathrm{CH}_{4}$ fluxes calculated with the MBR method also indicated a nighttime emission, similar to the pattern observed from the concentration gradient. During the observation period, the $\mathrm{CH}_{4}$ flux at night was $14.8 \pm$ $10.3 \mathrm{nmol} \mathrm{m} \mathrm{s}^{-2}$. Unfortunately, the $\mathrm{CH}_{4}$ fluxes from the MBR method during the daytime were not reliable due to the small $\mathrm{CH}_{4}$ and $\mathrm{CO}_{2}$ gradients.

\section{Discussion}

Plant-scale $\mathrm{CH}_{4}$ exchange

Comparison with published results

Corn is one of the most studied plant species regarding $\mathrm{CH}_{4}$ source/sink behavior. Table 1 presents a comprehensive summary of all known results. Our results are presented for the period between DOY 201 and 218 when LAI exceeded $5.1 \mathrm{~m}^{2} \mathrm{~m}^{-2}$ and the plant biomass density exceeded $202 \mathrm{gdw}_{\text {plant }}{ }^{-1}$. To facilitate the comparison, we multiplied the published values in units of $\mathrm{ng} \mathrm{CH}_{4} \mathrm{gdw}^{-1} \mathrm{~h}^{-1}$ by the mean dry biomass density over this period $\left(1,652 \mathrm{gdw} \mathrm{m}^{-2}\right)$ to obtain flux values in units of nmol m $\mathrm{m}^{-2} \mathrm{~s}^{-1}$. During this period, the midday flux was $0.11 \pm 0.06 \mathrm{nmol} \mathrm{m} \mathrm{m}^{-1}$. Beerling et al. (2008), Dueck and van der Werf (2008), Kirschbaum and Walcroft (2008), and Nisbet et al. (2009) all showed that the flux of the intact shoot and detached 

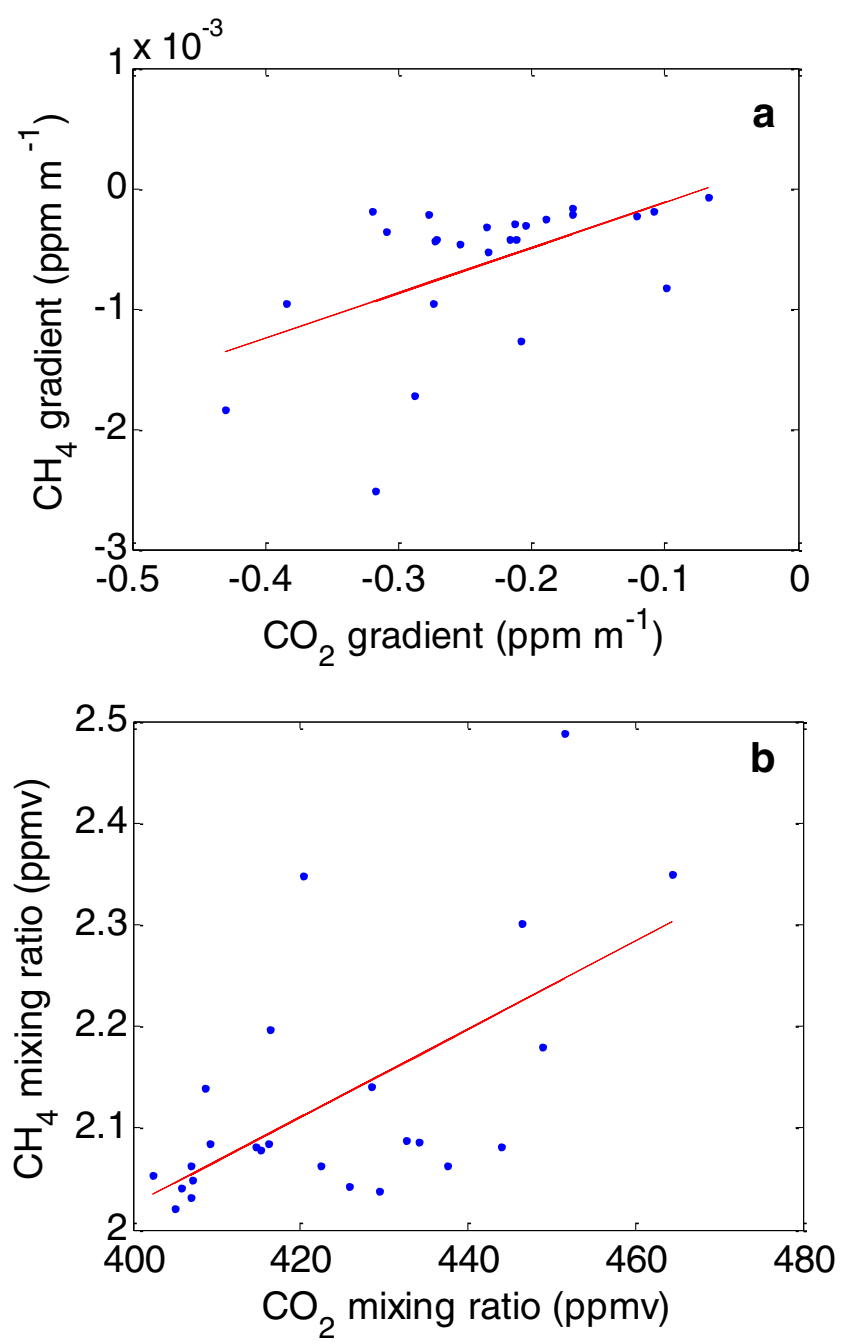

Fig. 9 Linear relationship between the night $\mathrm{CH}_{4}$ and $\mathrm{CO}_{2}$ gradients (a) and the $\mathrm{CH}_{4}$ and $\mathrm{CO}_{2}$ mixing ratios (b) at the $3 \mathrm{~m}$ height, DOY 243-269, 2009. The results of the linear regression are shown as red lines. Each data point represents a block average between 22:00 and 04:00 LST

leaves was not significantly different from zero. Vigano et al. (2008) reported that when UV radiation reaches $49 \mathrm{~W} \mathrm{~m}^{-2}$, fresh corn plant tissues emit $\mathrm{CH}_{4}$ at a rate of $50 \mathrm{ng} \mathrm{CH} \mathrm{gdw}^{-1} \mathrm{~h}^{-1}$, which is equivalent to $1.4 \mathrm{nmol} \mathrm{m}^{-2} \mathrm{~s}^{-1}$ or about ten times higher than our midday value. This difference could result from the difference in UV exposure. For instance, Vigano et al.'s UV flux intensity was twice as high as the average value in our experiment.

Some of the variations among these studies may have been a consequence of using different measurement methods and experimental conditions. To minimize measurement artifacts, we constructed the chamber system without impacting major physiological processes such as photosynthesis and respiration. In this design, special attention was given to temperature, radiation, and $\mathrm{CH}_{4}$ and $\mathrm{CO}_{2}$ background concentrations. The temperature inside the chamber was kept consistent with that of ambient air. The plexiglass chamber material had a transmissivity of $92 \%$ for visible light and $90 \%$ for UV radiation. The $\mathrm{CH}_{4}$ concentration inside the chamber was within 0.02 ppmv of the ambient value. On average, the $\mathrm{CO}_{2}$ concentration inside the chamber was 9 and 66 ppmv lower than ambient in the daytime and 4 and 11 ppmv higher than ambient at night during the soybean and corn growing seasons, respectively. The altered $\mathrm{CO}_{2}$ levels did not have an appreciable effect on plant function, at least from the perspective of $\mathrm{CO}_{2}$ exchange. For example, the midday $\mathrm{CO}_{2}$ uptake of unfertilized soybean and fertilized corn (from 10:00 to 16:00 LST) was $-12 \pm 3 \mu \mathrm{mol} \mathrm{m} \mathrm{m}^{-2} \mathrm{~s}^{-1}$ and $-39 \pm$ $3 \mu \mathrm{mol} \mathrm{m} \mathrm{m}^{-2} \mathrm{~s}^{-1}$, respectively (Fig. 7). These values were comparable to the plant flux derived from NEE and soil respiration measurements.

Keppler et al.'s (2006) results contrast sharply with ours and other studies. The mean flux of the four studies conducted in normal light levels (Berling et al. 2008; Dueck et al. 2007; Nisbet et al. 2009; this study) is $0.26 \pm$ $0.51 \mathrm{nmol} \mathrm{m} \mathrm{m}^{-2} \mathrm{~s}^{-1}$ and is one order of magnitude smaller than Keppler et al.'s flux value. Although this is not a new conclusion, the fact that our measurements were made in the field under near-ambient conditions further supports the view that extrapolation of Keppler et al.'s results to the global scale will severely overestimate the role of plants in the atmospheric $\mathrm{CH}_{4}$ budget (Ferretti et al. 2007; Houweling et al. 2006).

\section{Role of radiation}

That both corn and soybean emitted $\mathrm{CH}_{4}$ during the day and absorbed $\mathrm{CH}_{4}$ at night (Fig. 7) suggests a role of radiation in regulating plant $\mathrm{CH}_{4}$ exchange with the atmosphere. The day-to-day variations in $\mathrm{CH}_{4}$ production were correlated positively with solar radiation (Table 2). McLeod et al. (2008) and Vigano et al. $(2008,2009)$ found that the $\mathrm{CH}_{4}$ flux in dark conditions appears lower than if the plant is exposed to UV radiation, implying a photochemical production mechanism. Our results also reveal a negative correlation with the $\mathrm{CO}_{2}$ flux (Fig. 10, Table 2), raising another possibility that the daytime emission was linked to photosynthesis. The fact that Kirschbaum and Walcroft (2008) did not observe a significant $\mathrm{CH}_{4}$ flux may be related to the very low light intensity of their experiments (Table 1).

In the absence of solar radiation, the fertilized and unfertilized corn and soybean plants were small sinks of $\mathrm{CH}_{4}$ (Fig. 7). This uptake phenomenon, although rarely reported, is consistent with reports by Raghoebarsing et al. (2005) and Sundqvist et al. (2012), who suggest that plant $\mathrm{CH}_{4}$ uptake is an important sink in the global $\mathrm{CH}_{4}$ budget. In a boreal forest, the $\mathrm{CH}_{4}$ uptake by plants ranged up to 

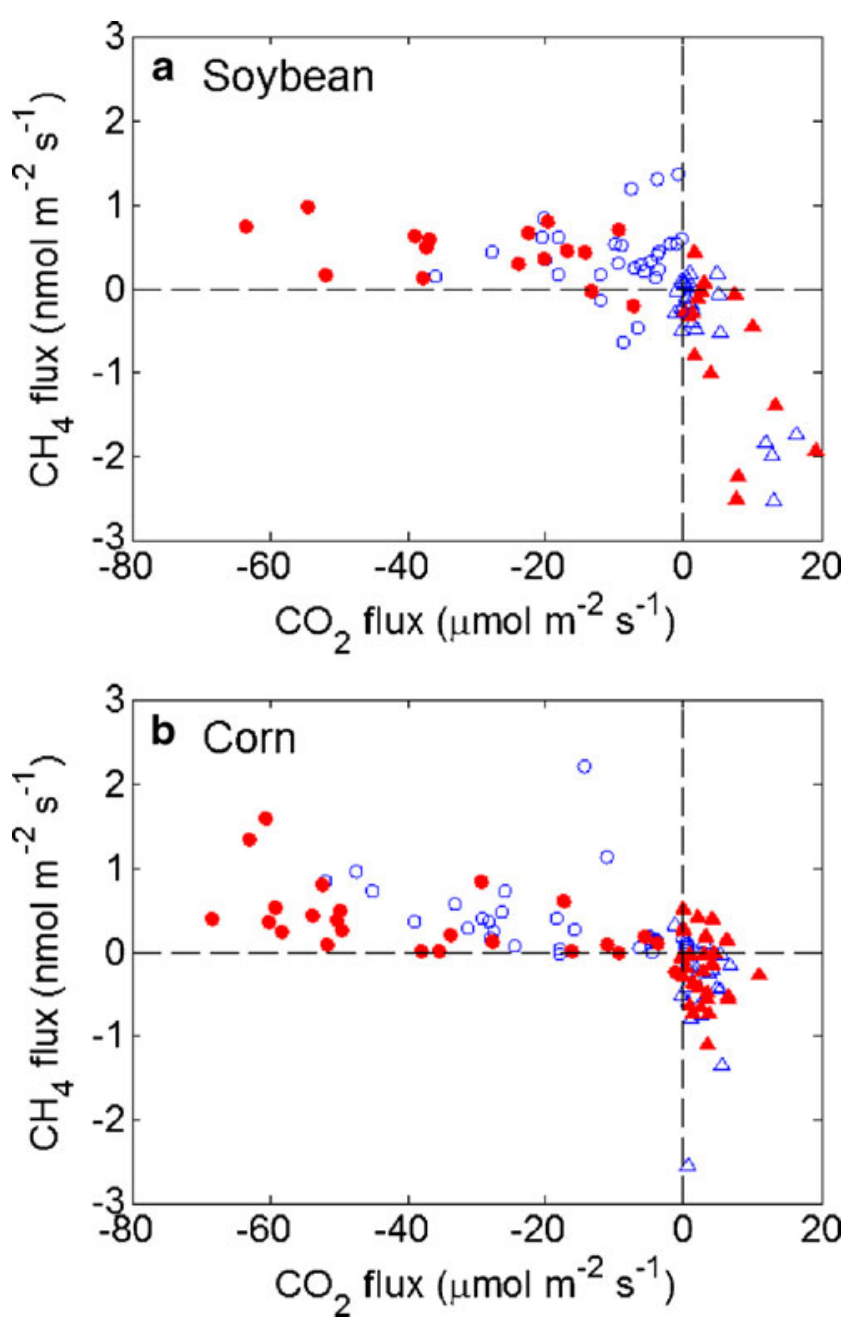

Fig. 10 Relationships between plant $\mathrm{CO}_{2}$ and $\mathrm{CH}_{4}$ fluxes. Red filled circles Midday fluxes from fertilized plants, blue open circles midday fluxes from unfertilized plants, red filled triangles midnight fluxes from fertilized plants, blue open triangles midnight fluxes from unfertilized plants. a Soybean, b corn

$0.94 \mathrm{nmol} \mathrm{m} \mathrm{s}^{-2}$, similar to the $\mathrm{CH}_{4}$ oxidation rate in soil (Sundqvist et al. 2012). Sphagnum mosses, prevalent plants in peat bogs, can uptake $\mathrm{CH}_{4}$ and the assimilated carbon from $\mathrm{CH}_{4}$ accounts for $10-15 \%$ of the carbon uptake by the plants (Raghoebarsing et al. 2005).

Three mechanisms have been proposed to explain plant uptake of $\mathrm{CH}_{4}$, including: (1) methanotrophic bacteria oxidize $\mathrm{CH}_{4}$ in soil, and plants act as a conduit of the soil flux; (2) the partly endophytic methanotrophic bacteria inside plants consume $\mathrm{CH}_{4}$ in stems and stem leaves (Raghoebarsing et al. 2005); and (3) the reactive oxygen species generated under environmental stress react with water to produce hydroxyl radicals $(\mathrm{OH})$, which is the major sink of $\mathrm{CH}_{4}$ (Logan et al. 1981). At this time it is not certain which of these mechanisms accounts for the uptake observed in our study, but an association with plant dark respiration was suggested by the correlation shown in Fig. 10.

Furthermore, all the mechanisms can take place during the daytime when the corn and soybean plants were a net source of $\mathrm{CH}_{4}$, suggesting that the gross $\mathrm{CH}_{4}$ production by plants may be much more than observed because part of it was recycled in the plant (Raghoebarsing et al. 2005). This internal recycling mechanism may prevent greater $\mathrm{CH}_{4}$ release to the atmosphere and lead to a negligible net $\mathrm{CH}_{4}$ flux from plants.

\section{Impact of fertilization}

Fertilization did not significantly affect the plant $\mathrm{CH}_{4}$ fluxes averaged over daily (24-h), midday, or midnight periods. However, although not statistically significant, the seasonal mean of $\mathrm{CH}_{4}$ uptake during the midnight periods was smaller in fertilized plots than in unfertilized plots for corn and soybean, and this was consistent with the impact of fertilization on agricultural soil reported in the literature (Jacinthe and Lal 2003; Mosier et al. 2006; Suwanwaree and Robertson 2005). A meta-analysis suggests that $\mathrm{CH}_{4}$ uptake by soil is inhibited by fertilization at a rate of $0.012 \pm$ $0.006 \mathrm{~kg} \mathrm{CH}_{4}-\mathrm{C} \mathrm{ha}^{-1}$ year $^{-1}$ per $1 \mathrm{~kg} \mathrm{~N} \mathrm{ha}^{-1}$ year $^{-1}$. By multiplying the fertilization rate for corn and soybean, respectively, soil $\mathrm{CH}_{4}$ uptake should have been reduced by $0.36 \pm 0.18 \mathrm{nmol} \mathrm{m}^{-2} \mathrm{~s}^{-1}$ and $1.6 \pm 0.8 \mathrm{nmol} \mathrm{m}^{-2} \mathrm{~s}^{-1}$. In comparison, the reduction in plant $\mathrm{CH}_{4}$ uptake during the midnight periods in our study was $0.13 \mathrm{nmol} \mathrm{m}^{-2} \mathrm{~s}^{-1}$ and $0.28 \mathrm{nmol} \mathrm{m}^{-2} \mathrm{~s}^{-1}$ for corn and soybean, respectively. Another recent study in the midwest US suggests that fertilization reduces soil uptake of $\mathrm{CH}_{4}$ by $0.19 \pm 0.25 \mathrm{nmol} \mathrm{m}^{-2} \mathrm{~s}^{-1}$ and $0.11 \pm 0.08 \mathrm{nmol} \mathrm{m}^{-2} \mathrm{~s}^{-1}$ in fields cultivated with corn and soybean (Johnson et al. 2010). The difference between the reduction in the soil $\mathrm{CH}_{4}$ uptake reported in the literature and our study suggests that applying the soil inhibition factor to plant $\mathrm{CH}_{4}$ flux may lead to an overestimation of the fertilization impact of as much as six times.

Landscape-scale flux and uncertainties

\section{Sources and sinks within the tower footprint}

To examine the contributions of other sources and sinks in the tower footprint, we conducted a source footprint analysis with the STILT model (Lin et al. 2003). At each time point, 100 air parcels were released at the receptor $\left(44^{\circ} 41^{\prime} 19^{\prime \prime} \mathrm{N}\right.$, $93^{\circ} 04^{\prime} 22^{\prime \prime} \mathrm{W}, 200 \mathrm{~m}$ ) and were transported backward for 2 days. The aggregated distribution of the air parcels defines the footprint of the tall tower. Overlaying this footprint map on the data on the type of land cover from the US Geological Survey, we estimated that $66 \%$ of the footprint during 
the observation period was cropland, $11 \%$ was grassland, $11 \%$ was forest, $2 \%$ was wetland, $4 \%$ was water, and $6 \%$ was developed land.

Even though the landscape is dominated by cropland, the flux from crop plants was negligible in the landscape-scale $\mathrm{CH}_{4}$ budget, since the plant flux was one to two orders of magnitude smaller than the landscape-scale $\mathrm{CH}_{4}$ flux. In midday, the (unfertilized) soybean and (fertilized) corn flux was $0.49 \pm 0.15 \mathrm{nmol} \mathrm{m}^{-2} \mathrm{~s}^{-1}$ and $0.37 \pm 0.18 \mathrm{nmol} \mathrm{m}^{-2} \mathrm{~s}^{-1}$, respectively, while at midnight, the soybean and corn flux was $-1.41 \pm 0.40 \mathrm{nmol} \mathrm{m} \mathrm{m}^{-2} \mathrm{~s}^{-1}$ and $-0.23 \pm$ $0.09 \mathrm{nmol} \mathrm{m} \mathrm{m}^{-2} \mathrm{~s}^{-1}$. In comparison, the landscape flux observed at the tall tower during the later growing season was $14.8 \mathrm{nmol} \mathrm{m}^{-2} \mathrm{~s}^{-1}$ at midnight.

Cropland soils in the Midwest US have been investigated intensively for $\mathrm{CH}_{4}$ flux (Alluvione et al. 2009; AdvientoBorbe et al. 2007; Mosier et al. 2006; Omonode et al. 2007; Ussiri et al. 2009). Divergence exists in the published results due to the complex production and consumption mechanisms of $\mathrm{CH}_{4}$ by methanogenesis and methanotropic bacteria. These studies show that the soil $\mathrm{CH}_{4}$ flux in corn or corn-soybean rotation croplands ranges from -0.94 to $0.73 \mathrm{nmol} \mathrm{m}^{-2} \mathrm{~s}^{-1}$. Adviento-Borbe et al. (2007) reported that the $\mathrm{CH}_{4}$ soil flux in a soybean-corn rotation field in eastern Nebraska was $-0.94 \mathrm{nmol} \mathrm{m} \mathrm{m}^{-2} \mathrm{~s}^{-1}$. Ussiri et al. (2009) suggested that tillage may have a significant impact on flux. In a comparative study in Ohio, the soil $\mathrm{CH}_{4}$ flux ranged from $-0.08 \mathrm{nmol} \mathrm{m} \mathrm{m}^{-2} \mathrm{~s}^{-1}$ under no-till to $0.73 \mathrm{nmol} \mathrm{m}^{-2} \mathrm{~s}^{-1}$ in a field subject to moldboard plowing. Omonode et al. (2007) reported that no-till fields emitted $\mathrm{CH}_{4}$ at a rate of $0.25 \mathrm{nmol} \mathrm{m} \mathrm{s}^{-2}$ and tilled fields were a net sink of $\mathrm{CH}_{4}$ at a rate of $-0.28 \mathrm{nmol} \mathrm{m}^{-2} \mathrm{~s}^{-1}$ in Indiana. Alluvione et al. (2009) and Mosier et al. (2006), however, found that tillage had a negligible impact on the $\mathrm{CH}_{4}$ soil flux in cornfields in Colorado, and Bavin et al. (2009) found it extremely difficult to even measure a significant $\mathrm{CH}_{4}$ flux from bare soils in strip till or conventional managed fields. The difference among these studies may be related to soil properties and to how many years the field has been in notill or till practice (Mosier et al. 2006). However, all observed fluxes, either positive or negative, were about one magnitude lower than the regional flux.

Native grassland and forest soils seem to have higher $\mathrm{CH}_{4}$ oxidation rates than cropland soils. In Inner Mongolia, the semi-arid grasslands consume $\mathrm{CH}_{4}$ at a rate of 0.48 to $0.61 \mathrm{nmol} \mathrm{m}^{-2} \mathrm{~s}^{-1}$ (Wang et al. 2005), while in the southern Rocky Mountains, forest soils take up $\mathrm{CH}_{4}$ at a rate of $1.2 \mathrm{nmol} \mathrm{m}^{-2} \mathrm{~s}^{-1}$ (Bowling et al. 2009). These findings are consistent with a comprehensive literature review by Le Mer and Roger (2001), which suggested that the $\mathrm{CH}_{4}$ consumption by upland soils ranges between 0 and $1.74 \mathrm{nmol} \mathrm{m}^{-2} \mathrm{~s}^{-1}$, depending on the disturbance regime such as tillage and fertilization (Le Mer and Roger 2001). As a result, grassland and forest may contribute mainly to the uptake of $\mathrm{CH}_{4}$ from the atmosphere, which was very likely offset by the emission from another type of land cover.

Wetland and developed land, two minor land use categories in the tower footprint, are strong sources of $\mathrm{CH}_{4}$. In one study, wetland $\mathrm{CH}_{4}$ emissions were estimated to be $61-$ $87 \mathrm{nmol} \mathrm{m}^{-2} \mathrm{~s}^{-1}$ in Minnesota in September (Shurpali and Verma 1998). A recent field experiment showed that the $\mathrm{CH}_{4}$ emission is about $20 \mathrm{nmol} \mathrm{m}{ }^{-2} \mathrm{~s}^{-1}$ in a boreal fen in western Canada (Long et al. 2010). In developed areas, $\mathrm{CH}_{4}$ can be emitted by fossil fuel combustion, landfills, and natural gas leakage (Mosher et al. 1999; Nakagawa et al. 2005; Zimnoch et al. 2010). Nakagawa et al. (2005) reported that automobile exhaust contributed up to $30 \%$ of $\mathrm{CH}_{4}$ sources in an urban area in Japan. An investigation by Mosher et al. (1999) at nine landfill sites in the northeastern US showed the emission rate of the landfills ranged from $6.6 \times 10^{3}$ to $9.4 \times 10^{4} \mathrm{nmol} \mathrm{m}^{-2} \mathrm{~s}^{-1}$. Regarding natural gas leakage, a study conducted in the urban area of Krakow, Poland, suggests that natural gas led to an emission flux of $14 \mathrm{nmol} \mathrm{m} \mathrm{m}^{-2} \mathrm{~s}^{-1}$ (Zimnoch et al. 2010). Consequently, even though wetland and developed land account for only $8 \%$ of the tall tower footprint, they may dominate the $\mathrm{CH}_{4}$ budget.

\section{Uncertainties in the MBR measurement}

The MBR method provided a more robust estimate of the $\mathrm{CH}_{4}$ flux under stable nighttime conditions than under unstable daytime conditions. The high $\mathrm{CH}_{4}$ concentration near the ground at night indicated that the ground surface was a source of $\mathrm{CH}_{4}$. Furthermore, the $\mathrm{CO}_{2}$ and $\mathrm{CH}_{4}$ vertical gradients were large at night and correlated with each other (Fig. 9a). The nighttime $\mathrm{CH}_{4}$ flux was $14.8 \mathrm{nmol} \mathrm{m}^{-2} \mathrm{~s}^{-1}$ according to the MBR method. For comparison, the midnight $\mathrm{CH}_{4}$ flux, obtained by multiplying the slope of the regression shown in Fig. 9b with the nighttime $\mathrm{CO}_{2}$ flux, was $17.1 \pm 9.4 \mathrm{nmol} \mathrm{m}^{-2} \mathrm{~s}^{-1}$. This latter estimate is independent of the assumption of equal eddy diffusivity between the two gases. Instead, this estimate assumes that the buildup of $\mathrm{CO}_{2}$ and $\mathrm{CH}_{4}$ in the stable air layer near the ground resulted from their respective land surface sources so that $\mathrm{CO}_{2}$ can be used as a tracer to constrain the $\mathrm{CH}_{4}$ surface flux. The same method was used by Kelliher et al. (2002) to determine the $\mathrm{N}_{2} \mathrm{O}$ flux in a grassland landscape affected by animal grazing.

It is not clear whether the regional daytime flux is positive or negative because the small daytime gradients are difficult to resolve. However, it is clear that the daytime $\mathrm{CH}_{4}$ flux is not large enough to decrease the daily averaged $\mathrm{CH}_{4}$ flux to the magnitude of the plant flux or even switch the sign of the flux. Zhang (2013) estimated the regional $\mathrm{CH}_{4}$ flux from the entire observation period with the equilibrium boundary layer method, and the result suggested the 
landscape around the tall tower emits $\mathrm{CH}_{4}$ at a rate of $16.0 \pm$ $3.1 \mathrm{nmol} \mathrm{m}^{-2} \mathrm{~s}^{-1}$, on the same magnitude as our MBR estimation at midnight. Based on a continuous gradient measurement on a tall tower in Wisconsin (about $260 \mathrm{~km}$ northeast of our tall tower), Werner et al. (2003) reported no diurnal pattern of $\mathrm{CH}_{4}$ flux and the regional $\mathrm{CH}_{4}$ emission rate in September was around $10 \mathrm{nmol} \mathrm{m} \mathrm{s}^{-1}$, similar to our observation. As a result, the nighttime $\mathrm{CH}_{4}$ flux estimated with the MBR method can provide a reasonable constraint on the $\mathrm{CH}_{4}$ budget during our observation period. Longer-term measurements and analyses are required to better understand the seasonal variability, annual budget, and source contributions of $\mathrm{CH}_{4}$ emissions in the upper Midwest.

\section{Conclusions}

We observed that soybean and corn plants emitted $\mathrm{CH}_{4}$ during the daytime (mean midday values $0.49 \pm 0.15 \mathrm{nmol} \mathrm{m}^{-2} \mathrm{~s}^{-1}$ and $0.37 \pm 0.18 \mathrm{nmol} \mathrm{m}^{-2} \mathrm{~s}^{-1}$, respectively) and absorbed $\mathrm{CH}_{4}$ during the nighttime (mean midnight values $-1.41 \pm$ $0.40 \mathrm{nmol} \mathrm{m} \mathrm{m}^{-1}$ and $\left.-0.23 \pm 0.09 \mathrm{nmol} \mathrm{m}^{-2} \mathrm{~s}^{-1}\right)$. The strength of the plant flux was at least one order of magnitude smaller than that suggested by Keppler et al. (2006). Fertilization did not have a significant impact on the plant $\mathrm{CH}_{4}$ flux. The plant $\mathrm{CH}_{4}$ flux was one to two orders of magnitude smaller than the landscape-scale $\mathrm{CH}_{4}$ flux measured at the tall tower $\left(14.8 \pm 10.3 \mathrm{nmol} \mathrm{m}^{-2} \mathrm{~s}^{-1}\right)$. Although the plant $\mathrm{CH}_{4}$ flux was relatively small, it indicates that there is a mechanism for cropland plants to uptake atmospheric $\mathrm{CH}_{4}$. Cropland plants, therefore, may represent an important sink in the global $\mathrm{CH}_{4}$ budget.

Acknowledgments We would like to thank the University of Minnesota UMore Park for use of the facilities. Funding was provided by the Ministry of Education of China (grant PCSIRT), the Rice Family Foundation, the Yale Institute for Biospheric Studies, and USDA NIFA/2010-65112-20528.

\section{References}

Adviento-Borbe MAA, Haddix ML, Binder DL, Walters DT, Dobermann A (2007) Soil greenhouse gas fluxes and global warming potential in four high-yielding maize systems. Glob Chang Biol 13:19721988

Alluvione F, Halvorson AD, Del Grosso SJ (2009) Nitrogen, tillage, and crop rotation effects on carbon dioxide and methane fluxes from irrigated cropping systems. J Environ Qual 38:2023-2033

Baker JM, Griffis TJ (2005) Examining strategies to improve the carbon balance of corn/soybean agriculture using eddy covariance and mass balance techniques. Agric For Meteorol 128:163-177
Bavin TK, Griffis TJ, Baker JM, Venterea RT (2009) Impact of reduced tillage and cover cropping on the greenhouse gas budget of amaize/soybean rotation ecosystem. Agric Ecosyst Environ 134:234-242

Beerling DJ, Gardiner T, Leggett G, McLeod A, Quick WP (2008) Missing methane emissions from leaves of terrestrial plants. Glob Chang Biol 14:1821-1826

Bowling DR, Miller JB, Rhodes ME, Burns SP, Monson RK, Baer D (2009) Soil, plant, and transport influences on methane in a subalpine forest under high ultraviolet irradiance. Biogeosciences 6:1311-1324

Bruhn D, Mikkelsen TN, Willats WGT, Ambus P (2009)Effects of temperature, ultraviolet radiation and pectin methylesterase on aerobic methane release from plant material. PlantBiol 11:4348, doi:10.1111/j.1438-8677.2009.00202.x

Bruhn D, Moller IM, Mikkelsen TN, Ambus P (2012) Terrestrial plant methane production and emission. Physiol Plant 144:201-209

Butenhoff CL, Khalil MAK (2007) Global methane emissions from terrestrial plants. Environ Sci Technol 41:4032-4037

Dueck T, van der Werf A (2008) Are plants precursors for methane? New Phytol 178:693-695

Dueck TA, de Visser R, Poorter H, Persijn S, Gorissen A, de Visser W, Schapendonk A, Verhagen J, Snel J, Harren FJM, Ngai AKY, Verstappen F, Bouwmeester H, Voesenek L, van der Werf A (2007) No evidence for substantial aerobic methane emission by terrestrial plants: a C-13-labelling approach. New Phytol 175:2935

Ferretti DF, Miller JB, White JWC, Lassey KR, Lowe DC, Etheridge DM (2007) Stable isotopes provide revised global limits of aerobic methane emissions from plants. Atmos Chem Phys 7:237-241

Griffis TJ, Lee X, Baker JM, Sargent SD, King JY (2005) Feasibility of quantifying ecosystem-atmosphere (COO)-O18-O-16 exchange using laser spectroscopy and the fluxgradient method. Agric For Meteorol 135:44-60

Griffis TJ, Baker JM, Sargent SD, Erickson M, Corcoran J, Chen $\mathrm{M}$, Billmark K (2010) Influence of $\mathrm{C}-4$ vegetation on $\left(\mathrm{CO}_{2}\right)$ $\mathrm{C}-13$ discrimination and isoforcing in the upper Midwest, United States. Glob Biogeochem Cycles 24:16

Hendriks DMD, van Huissteden J, Dolman AJ (2010) Multi-technique assessment of spatial and temporal variability of methane fluxes in a peat meadow. Agric For Meteorol 150:757-774

Houweling S, Rockmann T, Aben I, Keppler F, Krol M, Meirink JF, Dlugokencky EJ, Frankenberg C (2006) Atmospheric constraints on global emissions of methane from plants. Geophys Res Lett 33, L15821

Jacinthe PA, Lal R (2003) Nitrogen fertilization of wheat residue affecting nitrous oxide and methane emission from a central Ohio Luvisol. Biol Fertil Soils 37:338-347

Johnson JMF, Archer D, Barbour N (2010) Greenhouse gas emission from contrasting management scenarios in the northern corn belt. Soil Sci Soc Am J 74:396-406

Karlen DL, Duffy MD, Colvin TS (1995) Nutrient, labor, energy, and economic evaluations of two farming systems in Iowa. J Prod Agric 8:540-546

Kelliher FM, Reisinger AR, Martin RJ, Harvey MJ, Price SJ, Sherlock RR (2002) Measuring nitrous oxide emission rate from grazed pasture using Fourier-transform infrared spectroscopy in the nocturnal boundary layer. Agric For Meteorol 111:29-38

Keppler F, Hamilton JTG, Brass M, Rockmann T (2006) Methane emissions from terrestrial plants under aerobic conditions. Nature 439:187-191

Keppler F, Boros M, Frankenberg C, Lelieveld J, McLeod A, Pirttila AM, Rockmann T, Schnitzler JP (2009) Methane formation in aerobic environments. Environ Chem 6:459-465 
Kirschbaum MUF, Walcroft A (2008) No detectable aerobic methane efflux from plant material, nor from adsorption/desorption processes. Biogeosciences 5:1551-1558

Kroon PS, Hensen A, Jonker HJJ, Zahniser MS, van't Veen WH, Vermeulen AT (2007) Suitability of quantum cascade laser spectroscopy for $\mathrm{CH}_{4}$ and $\mathrm{N}_{2} \mathrm{O}$ eddy covariance flux measurements. Biogeosciences 4:715-728

Le Mer J, Roger P (2001) Production, oxidation, emission and consumption of methane by soils: a review. Eur J Soil Biol 37:25-50

Lin JC, Gerbig C, Wofsy SC, Andrews AE, Daube BC, Davis KJ, Grainger CA (2003) A near-field tool for simulating the upstream influence of atmospheric observations: the Stochastic Time-Inverted Lagrangian Transport (STILT) model. J Geophys Res-Atmos 108(D16):4493

Liu LL, Greaver TL (2009) A review of nitrogen enrichment effects on three biogenic GHGs: the $\mathrm{CO} 2$ sink may be largely offset by stimulated $\mathrm{N} 2 \mathrm{O}$ and $\mathrm{CH} 4$ emission. Ecol Lett 12:1103-1117

Logan JA, Prather MJ, Wofsy JC, McElroy MB (1981) Tropospheric chemistry: a global perspective. J Geophys Res 86:7210-7254

Long KD, Flanagan LB, Cai T (2010) Diurnal and seasonal variation in methane emissions in a northern Canadian peatland measured by eddy covariance. Glob Chang Biol 16:2420-2435

McLeod AR, Fry SC, Loake GJ, Messenger DJ, Reay DS, Smith KA, Yun BW (2008) Ultraviolet radiation drives methane emissions from terrestrial plant pectins. New Phytol 180:124-132

Meyers TP, Hall ME, Lindberg SE, Kim K (1996) Use of the modified Bowen-ratio technique to measure fluxes of trace gases. Atmos Environ 30:3321-3329

Mosher BW, Czepiel PM, Harriss RC, Shorter JH, Kolb CE, McManus JB, Allwine E, Lamb BK (1999) Methane emissions at nine landfill sites in the northeastern United States. Environ Sci Technol 33:2088-2094

Mosier AR, Halvorson AD, Reule CA, Liu XJJ (2006) Net global warming potential and greenhouse gas intensity in irrigated cropping systems in northeastern Colorado. J Environ Qual 35:1584-1598

Nakagawa F, Tsunogai U, Komatsu DD, Yamada K, Yoshida N, Moriizumi J, Nagamine K, Iida T, Ikebe Y (2005) Automobile exhaust as a source of C-13- and D-enriched atmospheric methane in urban areas. Org Geochem 36:727-738

Nisbet RER, Fisher R, Nimmo RH, Bendall DS, Crill PM, Gallego-Sala AV, Hornibrook ERC, Lopez-Juez E, Lowry D, Nisbet PBR, Shuckburgh EF, Sriskantharajah S, Howe CJ, Nisbet EG (2009) Emission of methane from plants. Proc R Soc B Biol Sci 276:1347-1354

Omonode RA, Vyn TJ, Smith DR, Hegymegi P, Gal A (2007) Soil carbon dioxide and methane fluxes from long-term tillage systems in continuous corn and corn-soybean rotations. Soil Tillage Res 95:182-195

Parsons AJ, Newton PCD, Clark H, Kelliher FM (2006) Scaling methane emissions from vegetation. Trends Ecol Evol 21:423-424

Pattey E, Strachan IB, Desjardins RL, Edwards GC, Dow D, MacPherson JI (2006) Application of a tunable diode laser to the measurement of $\mathrm{CH} 4$ and $\mathrm{N} 2 \mathrm{O}$ fluxes from field to landscape scale using several micrometeorological techniques. Agric For Meteorol 136:222-236

Qaderi MM, Reid DM (2011) Stressed crops emit more methane despite the mitigating effects of elevated carbon dioxide. Funct Plant Biol 38:97-105

Raghoebarsing AA, Smolders AJP, Schmid MC, Rijpstra WIC, WoltersArts M, Derksen J, Jetten MSM, Schouten S, Damste JSS, Lamers
LPM, Roelofs JGM, den Camp HJMO, Strous M (2005) Methanotrophic symbionts provide carbon for photosynthesis in peat bogs. Nature 436(7054):1153-1156

Shurpali NJ, Verma SB (1998) Micrometeorological measurements of methane flux in a Minnesota peatland during two growing seasons. Biogeochemistry 40:1-15

Shurpali NJ, Verma SB, Clement RJ, Billesbach DP (1993) Seasonal distribution of methane flux in a Minnesota peatland measured by eddy-correlation. J Geophys Res Atmos 98:20649-20655

Smeets C, Holzinger R, Vigano I, Goldstein AH, Rockmann T (2009) Eddy covariance methane measurements at a Ponderosa pine plantation in California. Atmos Chem Phys 9:8365-8375

Sundqvist E, Crill P, Mölder M, Vestin P, Lindroth A (2012) Atmospheric methane removal by boreal plants. Geophys Res Lett 39:L21806

Suwanwaree P, Robertson GP (2005) Methane oxidation in forest, successional, and no-till agricultural ecosystems: Effects of nitrogen and soil disturbance. Soil Sci Soc Am J 69:1722-1729

United States Department of Agriculture (2009) US Summary and State Data 2007 Census. Rep Agric 1:7-16

Ussiri DAN, Lal R, Jarecki MK (2009) Nitrous oxide and methane emissions from long-term tillage under a continuous corn cropping system in Ohio. Soil Tillage Res 104:247-255

Vigano I, van Weelden H, Holzinger R, Keppler F, McLeod A, Rockmann T (2008) Effect of UV radiation and temperature on the emission of methane from plant biomass and structural components. Biogeosciences 5:937-947

Vigano I, Holzinger R, Rockmann T, van Dijk A, Keppler F, Greule M, Brand WA, van Weelden H, van Dongen J (2009) UV light induces methane emission from plant biomass: mechanism and isotope studies. Geochim Cosmochim Acta 73:A1382-A1382

Wang YS, Xue M, Zheng XH, Ji BM, Du R, Wang YF (2005) Effects of environmental factors on $\mathrm{N} 2 \mathrm{O}$ emission from and $\mathrm{CH} 4$ uptake by the typical grasslands in the Inner Mongolia. Chemosphere 58:205-215

Wang ZP, Han XG, Wang GG, Song Y, Gulledge J (2008) Aerobic methane emission from plants in the Inner Mongolia steppe. Environ Sci Technol 42:62-68

Wang ZP, Gulledge J, Zheng JQ, Liu W, Li LH, Han XG (2009) Physical injury stimulates aerobic methane emissions from terrestrial plants. Biogeosciences 6:615-621

Wang ZP, Keppler F, Greule M, Hamilton JTG (2011) Non-microbial methane emissions from fresh leaves: effects of physical wounding and anoxia. Atmos Environ 45:4915-4921

Werner C, Davis K, Bakwin P, Yi CX, Hurst D, Lock L (2003) Regional-scale measurements of $\mathrm{CH} 4$ exchange from a tall tower over a mixed temperate/boreal lowland and wetland forest. Glob Chang Biol 9:1251-1261

Wishkerman A, Greiner S, Ghyczy M, Boros M, Rausch T, Lenhart K, Keppler F (2011) Enhanced formation of methane in plant cell cultures by inhibition of cytochrome $c$ oxidase. Plant Cell Environ 34:457-464

Zhang X (2013) Improving regional-scale greenhouse gas inventories in an agriculturedominated landscape using a multi-scale approach. PhD Dissertation, Yale University

Zhao CF, Andrews AE, Bianco L, Eluszkiewicz J, Hirsch A, MacDonald C, Nehrkorn T, Fischer ML (2009) Atmospheric inverse estimates of methane emissions from Central California. J Geophys Res Atmos 114, D16302

Zimnoch M, Godlowska J, Necki JM, Rozanski K (2010) Assessing surface fluxes of $\mathrm{CO} 2$ and $\mathrm{CH} 4$ in urban environment: a reconnaissance study in Krakow, Southern Poland. Tellus Ser B Chem Phys Meteorol 62:573-580 